\title{
THE GREEK-SPEAKING POPULATION OF SOUTHERN ITALY.
}

IT will probably be a surprise, even to readers of the Journal of Hellenic Studies, to learn that there are at the present day twenty thousand persons in the south of Iialy who speak Greek as their native tongue. These people form two separate groups, composed of a number of villages or townships, one of which is found in the heel of Italy or Terra d'Otranto, the other in the toe of that country, towards the extremity of the modern Calabria, in the neighbourhood of Cape Spartivento, and about twenty miles to the south-east of Reggio. The language which they speak, as might well be supposed, is not ancient Greek; nor is it in any sense a lineal descendant of that which was spoken in the colonies of Magna Graecia; but, though it is essentially modern Greek, it differs considerably from the Romaic of Greece, and these differences are of such a nature, that it must have required the lapse of many centuries to produce them. There can be no doubt that at one time it was spoken over a much wider area than at present; indeed, within the memory of man it has died out, and has been superseded by Italian, in places where it had previously been in use. Any traditions which may have existed with regard to the origin of this people and the fortunes of their ancestors they have now entirely lost; and their history, as far as it can be discovered at all, must be reconstructed from casual notices in historical documents and from intimations contained in the language. The object of the present paper is to draw attention to some of the more salient characteristics of that language, and to the poems which have been composed in it; and afterwards to discuss the evidence which may be drawn from these and other sources with regard to the immigration of these Greeks into Italy. The information which it contains is mainly drawn from the works of earlier authorities, of whose learned labours some account will be given later on; but during the autumn of 1887 I myself visited both these colonies, with the object of inquiring into their present condition, and of verifying a number of interesting points relating to the language. My informants on the spot (to whom I desire to tender my sincere thanks) were two intelligent Greeks-for the Otranto district, the parish priest of Sternatia, the Rev. Giuseppe Ancora; for the Calabrian group, Sig. Vitale Pietro, the schoolmaster of Bova.

The peninsula which forms the heel of Italy, starting, as its base, from a line drawn across from Brindisi to Taranto, is throughout its whole area a slightly undulating level, and Lecce, which is its principal city, stands near 
its centre. It is in the inland region to the southward of that place that the towns and villages lie where Greek is spoken. At the present time they are nine in number, containing fifteen thousand inhabitants in all, viz. Martáno, Caliméra, Melpignáno, Castrignáno, Zollíno, Martignáno, Sternatía, Soléto, and Corigliano. Of these, Zollino forms the junction, where the railway which runs south from Lecce divides into two branches, one of which reaches the sea at Otranto towards the south-east, the other at Gallipoli towards the south-west; and the other towns lie either on, or at no great distance from, one or other of those lines. The position which is occupied by the Greek settlements in Calabria forms a strong contrast to this, for it is completely a mountain region. The traveller, indeed, who passes Cape Spartivento in the train, may see a station named Bova on the sea-coast; but the town of that name, which is the head-quarters of this colony, and is called Vua (Bova) by its inhabitants, lies eight miles inland, on the summit of a peak 3,000 feet above the sea, and can only be reached by a steep foot-path. Its strange situation recalls that of Sta Agnese, the hill-town at the back of Mentone. Within, owing to the ruggedness of the ground, the houses are piled irregularly on one another, and the streets zigzag at odd angles. Its various localities bear Greek names; one square is called Amalía (i.e. 'O $\mu a \lambda i$ ia $^{\circ}$ ), the level,' another Itonía (i.e. Teıтovía) Megále, 'the great neighbourhood'; a street is named Aion Tríphono (San Trifone); and the three fountains are Siphóni, Petrophýlaco, and Cleisté, the last of these being a double spring, with a trough for washing, covered in by an arch of masonry. The other

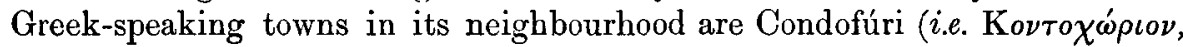
or 'the village near' Bova), with Amendoléa and Gallicianó; Roccaforte, called by the Greeks Vuní or 'mountain-town' (Bovviov); and Rofúdi or

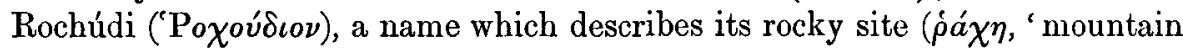
ridge'). The population of these amounts to five thousand. At Cardeto, where a peculiar dialect, differing in many important points from those of its neighbours, was until lately in use, the Greek language has now disappeared -fortunately, not before its pronunciation had been observed and its vocabulary and grammatical forms had been registered. Another trace of a wider diffusion of the language and people remains in the name Pentedattilo, the same which, in its more accurate form of Pentedactylon, is familiar to the traveller in the Peloponnese as the modern appellation of Taygetus. Here it is attached to a steep and solitary mass of rock, rising into five columnar peaks, which forms a conspicuous object in the view from the sea, as the voyager passes out of the Straits of Messina on his way to Greece. The village of the same name, which occupies a precipitous position on its landward side, no doubt was once Greek, but now its inhabitants are merged in the surrounding Italian population.

The Greeks of Bova appear to be much poorer than those of the Terra d'Otranto-a result which might naturally arise from the country which they inhabit being less productive and harder to cultivate; but in both districts the pursuits of the people are almost entirely agricultural, and notwithstanding that they live within easy reach of the sea, they never go abroad or engage in 
commerce. Though a few of the peasants who live at a distance from the town of Bova speak Greek only, yet the great majority, both there and in the heel of Italy, are bilingual, being equally familiar with Greek and Italian. From this fact it would be natural to conclude that they are losing their native language, especially as we find that the same process of change has already been going on; and in the Terra d'Otranto, where the progress of railways has brought them into closer communication with the outer world, it might be expected that they would be rapidly assimilated. But in reality this has not happened, and the anticipation of Morosi, the chief authority on subjects relating to them, who, writing in 1870 , expressed his belief that in two generations the Greek language in these parts would be extinct, has not been verified. On the contrary, I was assured by members of both groups that at the present time they have no fear of this result. Up to seven years of age, they said, the children speak nothing but Greek; and though in the schools their instruction is confined to Italian, yet, like the Highlanders with their Gaelic, in their families they only employ their native tongue, and they are very tenacious in retaining it. Still, it is difficult to see bow they can for any length of time resist the influences by which they are surrounded, when the counteracting forces are wanting by which the tide might be stemmed. In the first place, they possess no Greek books, and do not use the Greek character in writing. To the philologist who investigates their language the advantage of this is great, because the dialects retain their purity, and cannot be tampered with by the introduction of classical forms ; but, at the same time, it is almost impossible to retain a language permanently, in the face of one that is more dominant, without a written literature. Again, they have no feeling of nationality to support them. Of the kingdom of Greece they know nothing, and when I talked to them on the subject, they manifested no interest in it or in the Greek people. The two groups of Greeks in Italy, of whom I am speaking, though they are aware of one another's existence, are mutually unacquainted, and no communication ever passes between them. The Greek colony that is settled in Corsica is unknown to them. Politically, their desire is to be regarded as good Italian subjects, and in conversation they identify themselves with Italy and its interests. Though they rarely intermarry with their Italian neighbours, yet they are on good terms with them; and the bar of religious difference, which must once have interposed between them, has been removed by centuries of conformity to the Western rite. A trace of former antagonism, combined perhaps with a reminiscence of the early ecclesiastical distinction, is found in their still calling the Italians 'Latins' ( $\Lambda a \tau \hat{\imath} \nu \circ \iota)$; as, for instance, in a love-song, where the lover tells his lady that he wishes to teach her a sonnet in Greek, in order that the 'Latins' may not understand what he says:-

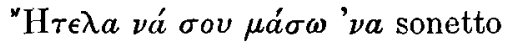

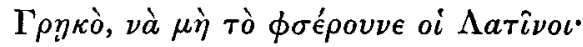

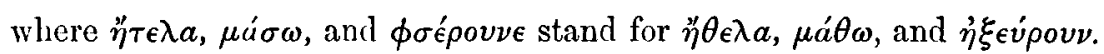

The earliest inquiries that were made concerning this people and their 
language are associated with a number of distinguished literary names. Though vague intimations of their existence had been furnished by travellers, such as Swinburne, Eustace, and Keppel Craven, yet the first person who really threw light on the subject, and brought it under the notice of men of letters, was Carl Witte, the famous Dante scholar. When journeying as a young man in South Italy, he was informed at Reggio that there were Greeks in that neighbourhood, and accordingly he put himself at once in communication with some of the inhabitants of the Bova district. The result was that he succeeded in writing down from the mouth of the people in Roman letters about fifty Greek words, together with three songs; and these he afterwards submitted to Cardinal Mezzofanti, who transcribed them-with a somewhat free adaptation, it must be allowed-into Greek. One of the songs was published by Witte in 1821 in the Gesellschafter, together with a short introductory notice, in which he advocated the notion, that the dialect in which it was composed was independent of Modern Greek, and had descended in a direct line from the speech of Magna Graecia. This seems to have attracted little notice at the time, and must have been unknown to Niebuhr, when, six years later, he published the first volume of his History of Rome; otherwise he would certainly have cited it in support of the view expressed in the following passage, which is still interesting, though it is now acknowledged to be untenable.

'Calabria, like Sicily, continued to be a Greek country, though the Romans planted colonies on the coasts. The Greek language did not begin to give way there till the fourteenth century: it is known to have prevailed not three hundred years since at Rossano, and no doubt much more extensively; for our knowledge of the fact as to that little town is merely accidental. Nay, at this day there is a population that speaks Greek remaining in the neighbourhood of Locri.' 1

It happened, however, that, long after this, Witte chanced to broach the subject in the course of a conversation with Prof. A. F. Pott; and that distinguished philologist became so much interested in the question, that he obtained leave to publish all three of the songs, as well as Witte's list of words; this he did in 1856 in the eleventh volume of the Philologis, in a paper entitled 'Altgriechisch im heutigen Calabrien?' He there confutes Niebuhr's and Witte's view of the continuity of the Greek race and language in Italy by a minute examination of the vocabulary and inflexions, in which be shows that they are closely allied to those now in use in Greece.

The inquiry, which thus far had been pursued in a somewhat dilettante spirit, was now taken in hand in good earnest by the Italians themselves. To pass over a number of minor contributions to the subject-in 1866 Prof. Comparetti published at Pisa, under the title of Saggi dei dialetti greci dell' Italia Meridionale, a collection of forty-three poems, thirty-eight of which were from Bova-having been for the most part obtained for him by a former

1 Niebuhr, History of Rome (Eng. trans.), i. 62. In his note to this passage, the author refers to the Neapolitan minister, Count Zurlo, as his authority for the last statement. 
pupil of his, Prof. Terra of Reggio-and the remaining five from the Terra d'Otranto. The introduction and notes to this volume are of great value on account of the accomplished writer's intimate acquaintance with the Modern Greek language and its dialects. In 1867 Prof. Morosi, who had been appointed to a post in Lecce, set to work to study on the spot the language of the Greeks in those parts, and to collect their literature; and the result of his labours appeared in his Studi sui dialetti greci della Terra d'Otranto (Lecce, 1870). This admirable book, which is a model of acute and thoroughly scientific investigation in the domain of philology, contains 177 songs, and a collection of stories and proverbs in prose, with Italian translations; a critical review of these compositions; a grammar, in which the sounds of the language and the changes which they have undergone, and the system of inflexions, are fully set forth; a glossary of the most important words ; and a historical essay on the origin and history of this Greek colony. The poems have here been arranged according to the townships from which they come, so that the dialectic peculiarities of each can be studied separately; and in other ways the careful manner in which the linguistic features of each community have been distinguished is singularly instructive to the student of dialects. The only point in Prof. Morosi's treatment of his subject to which exception can be taken, is his too great fondness for discovering traces of the classical dialects-Aeolic, Doric, and Ionic-in the modern Greek language, a view which is rapidly losing ground at the present time. In 1874 the same writer published another book on the poems and the language of the Calabrian Greeks-Dialetti romaici del Mandamento di Bova in Calabria-which is arranged according to the same method, and is distinguished by the same merits, as its predecessor. Finally, in 1880, Prof. Pellegrini, who during his residence as professor at Reggio had investigated the subject independently, in a volume entitled $I l$ dialetto greco-calabro di Bova printed seventy-five songs from that district, thirty-eight of which then appeared for the first time; the remainder were the same which Comparetti had previously published, but in the case of twenty-five of them the new editor obtained fresh, and in some points different, versions. To these he added translations of the story of Joseph and his brethren, and of the parable of the Prodigal Son, in the Greek of Bova; and an excellent lexicon, in which the words of this dialect are compared with those which correspond to them in the dialect of the Terra d'Otranto, and in Modern Greek. ${ }^{1}$ In the works of the three authors who have been mentioned in this paragraph the subject may be said to have been thoroughly sifted; and it is to them that I am indebted for the materials of which this article is composed.

It is obviously impossible for me within my present limits to give, even in outline, an account of these dialects; and for this I may refer the reader to Morosi's publications, though that which relates to the Terra d'Otranto is, I grieve to say, extremely rare. But in order to render the specimens of the

\footnotetext{
1 The second volume of this work, which was and general conclusions, has never appeared.
} to have contained the phonolngy, morphology, 
literature which follow more intelligible than they otherwise might be, as well as on account of the interest of the subject itself, it may be well that I should here draw attention to some of their more salient peculiarities, and especially to those in which they differ from ordinary Modern Greek. For clearness sake I will mention first those that are found (with slight differences) in both dialects, and afterwards those that are confined to the Otrantine and the Calabrian respectively. It may be convenient to use the following abbreviations. A.G. for Ancient Greek, M.G. for Modern Greek, Otr. for the Greek of the Terra d'Otranto, Bov. for that of Bova.

\section{General Remarks on both Dialects.}

SoUnDs.-(1) The pronunciation both of vowels and consonants is in most points the same as in Greece, and itacism prevails to the same extent; but $\boldsymbol{\kappa}$ is soft (Eng. $c h$ ) before soft vowels, as it is also in many of the Greek islands and in the south of the Morea. In Otr. also the letter $\delta$, which in M.G. and Bov. has the sound of soft th (as in Eng. $t h i s$ ), is pronounced like d. (2) Owing to the influence of the Calabrian and other neighbouring dialects of Italian, which substitute $d d$ for $l l$, in the Greek dialects $\lambda \lambda$ becomes

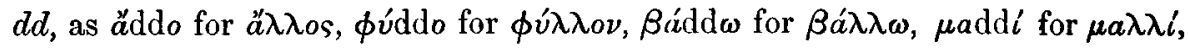
'hair'; and the same is the case with $\lambda$ between vowels, as $a \pi \rho i d d \iota$ for

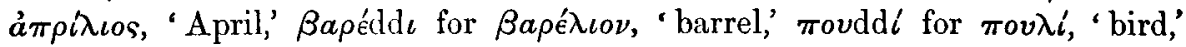
$\pi \epsilon \rho \delta \iota \kappa o \hat{v d d} a$ for $\pi \epsilon \rho \delta \iota \kappa o v \lambda a$, 'partridge.' It is noticeable that in one place, the village of Cardeto near Bova, where the Greek language has recently become extinct, this change did not occur, but the original sound of $\lambda \lambda$ was retained. (3) Probably the influence of the Italian dialects also caused the broad $u$-sound (ov) frequently to take the place of $o:$ the $u$-sound predominates in Calabrian, as mancu for manco, sulo for solo, dopu for dopo; and, though it is often found taking the place of $\omega$ in M.G. dialects, as кátov for

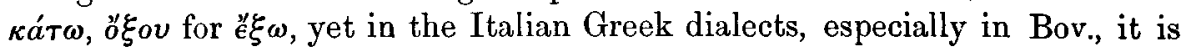

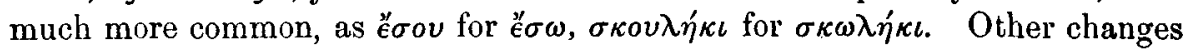
in words fall under the following heads. (4) Assimilation; as Otr. $\lambda$ úvvo for

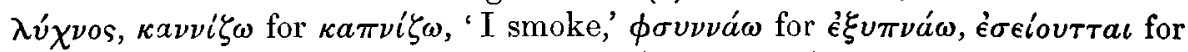

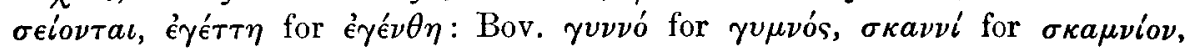
$\pi \varepsilon ́ \tau \tau \omega$ for M.G. $\pi \varepsilon ́ \phi \tau \omega(\pi i \pi \tau \omega)$. (5) Transposition of consonants; as Otr.

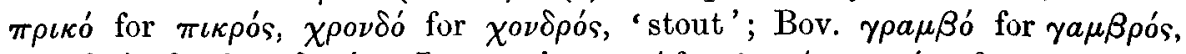

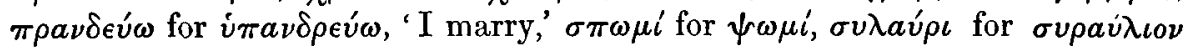

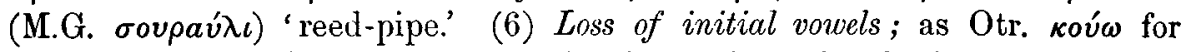

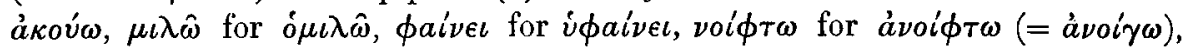

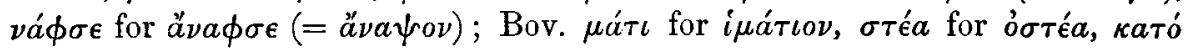

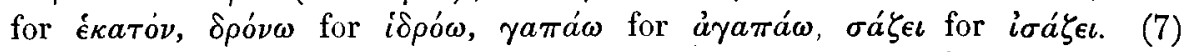

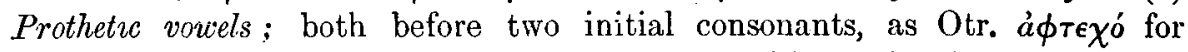

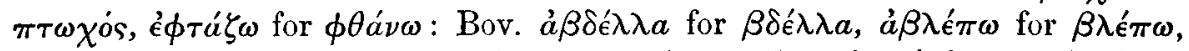

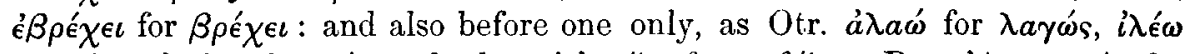

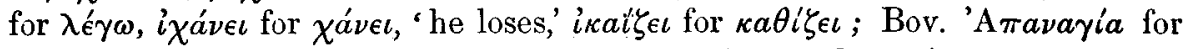

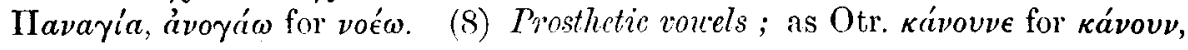




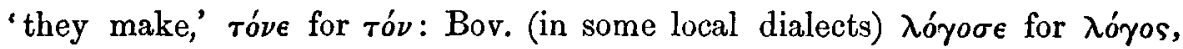
$\dot{\eta} \mu \epsilon \hat{i} \sigma \epsilon$ for $\dot{\eta} \mu \epsilon \hat{\imath}$. Changes corresponding in principle to those enumerated under the last five heads are found also in the dialects of Modern Greek.

Accents.-These are generally the same as in M.G., but in both the

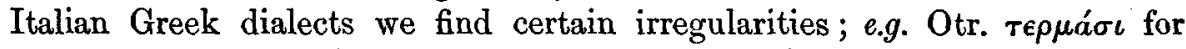

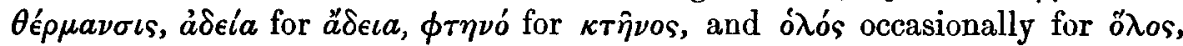
though in this word the accentuation varies: Bov. $\chi^{a} \mu a \iota$ for $\chi a \mu a l, a \dot{\nu} \iota \zeta i^{\prime}$

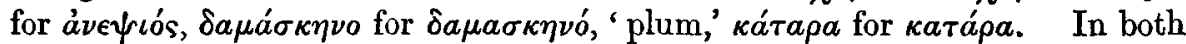
dialects the plural of $a \nu \nu \rho \omega \pi o s$ does not retain its normal accent; in Otr. we

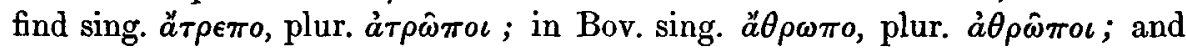
a similar irregularity is found in some other words, as ámó In both, also, the adverb signifying 'yet,' 'still,' which in M.G. is áкó $\mu \eta$, appears as $\dot{\alpha} \kappa о \mu \eta \dot{~: ~ p o s s i b l y, ~ h o w e v e r, ~ t h i s ~ i s ~ n o t ~ a ~ c o r r u p t i o n, ~ b u t ~ a ~ r e t e n t i o n ~}$ of the accent of the classical $\dot{a} \kappa \mu \eta_{\nu}$, from which the word is derived, and which is found in this sense from the time of Theocritus onwards. In both

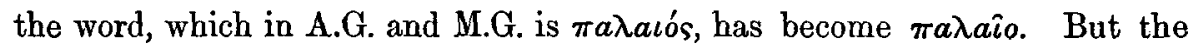
most remarkable change is that which has befallen av́ós, which in Otr. is

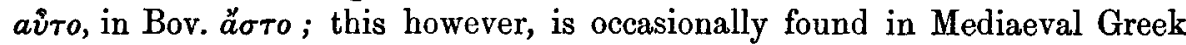
(see J.H.S. vol. iv. pp. 205, 213) It is noticeable, also, that the tendency to throw forward the accent of words on to the final syllable, which is so common

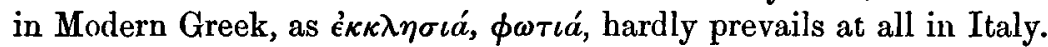

INFLEXIONS.-In these the most marked peculiarity is the loss of final consonants, which is probably attributable in great measure to the influence of Italian. In Modern Greek $\nu$ is constantly dropped at the end of the nom.

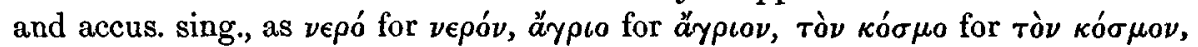
$\tau \grave{\eta} \nu \theta a ́ \lambda a \sigma \sigma a$ for $\tau \grave{\eta} \nu \theta a ́ \lambda a \sigma \sigma a \nu$ : and occasionally in verb. forms, as $\eta \tilde{v} \rho a \mu \epsilon$ for $\eta \tilde{v} \rho a \mu \epsilon \nu$ \&c. : but here both $\nu$ and $s$ are regularly lost in all cases of nouns and persons of verbs, unless they are followed by an initial vowel, or, in the case of $\nu$, by a guttural. Considerable confusion has thus been introduced

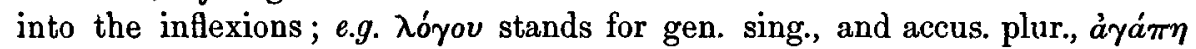

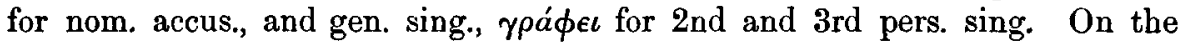
other hand, not only $\nu$, but also $s$ is occasionally interposed to prevent hiatus between words; and in the gen. plur. in Otr. the s has come to be usually attached to the form, when it is followed by an initial vowel, the $\nu$ having been previously lost, as $\tau \hat{\omega} s \dot{a} \pi \epsilon \sigma a \mu \mu \epsilon \in \omega \omega$ for $\tau \hat{\omega} \nu \dot{a} \pi o \theta a \mu \mu \epsilon^{\prime} \nu \omega \nu$. The article has especially suffered in this way, because throughout its declension it has

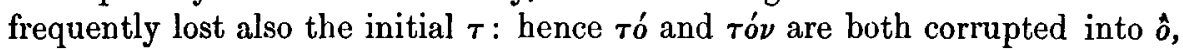
and thus become indistinguishable from $\delta$, since here, as elsewhere in Modern Greek, the sound of the aspirate is lost. Both in Otr. and Bov. much irregularity has crept into the use of the gender of the article, the masc. and neut.

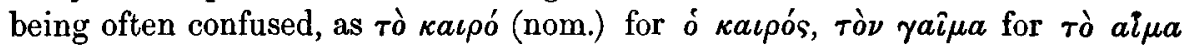
(accus.). The dative case is lost, and has usually been replaced by the genitive, as $\sigma o \hat{v}$ '́ $\sigma \tau \epsilon \iota \lambda \epsilon$, ' he sent to you'; more rarely by the accusative with a preposition. Verbs with vowel-stems generally insert a consonant (which in the majority of cases is $\nu$ ) after the stem in the present tense; as $\kappa \lambda \alpha^{\prime} \nu \omega$ for

H.S.--VOI. $\mathrm{x}$. 


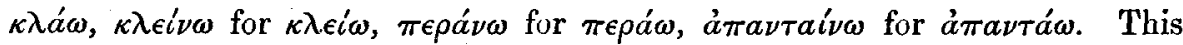
feature, which is of common occurrence in Greece, is especially prevalent in the dialect of Bova, but it applies less to verbs in $-\epsilon \omega$ than to other contract verbs; these however have not retained their original form, but in most cases

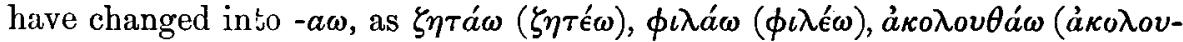
$\theta \dot{\epsilon} \omega)$. Italian verbs, when they are imported or borrowed, as they have been

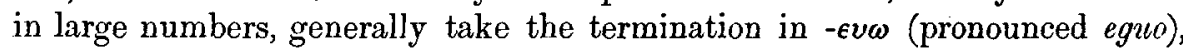

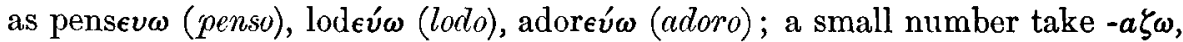
as mugghiáļ (mugghio).

Words.-The negative, which in M.G. is $\delta^{\prime} e^{\prime}$ (oủ $\delta \varepsilon^{\prime} \nu$ ), in Bov. takes the

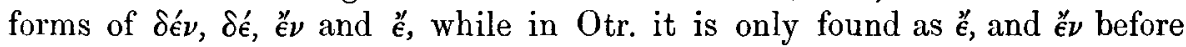
vowels. In both dialects 'neither-nor,' is expressed by $\delta \epsilon-\delta \epsilon$, , and the prohibitive particle is $\mu \eta^{\prime}, \mu \eta^{\prime} \nu$. 'No one' is $\tau i \sigma \pi o$, i.e. $\tau i$ 's $\pi \circ \tau \epsilon$, the interrogative being used for the negative: it is natural to suppose that this form must once

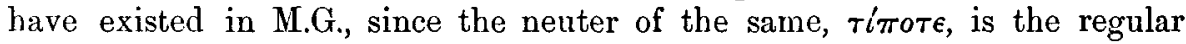
word for 'nothing' in that language. Otr. '̈Tov, Bov. ڤ̈tov, 'thus,' are from

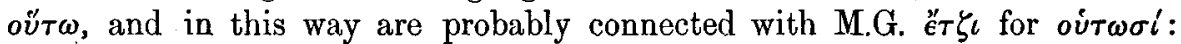

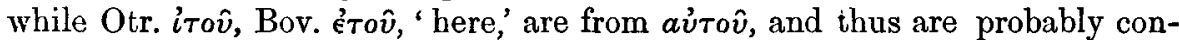

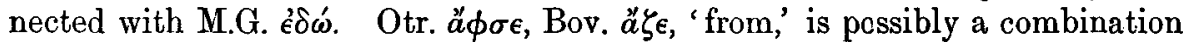

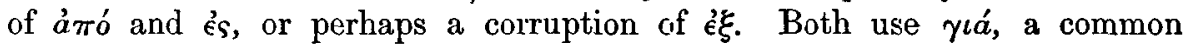
dialectic M.G. form of $\delta \iota a ́$, which in Otr. sometimes is lengthened into rıáï: this is to be distinguished from rıai', 'because,' which is for M.G. $\delta \iota a r i$ (= $\left.\delta \iota \tau^{\prime} \iota\right)$. The change in the meaning of words from that which they bear in ancient and modern Greek is often instructive. Both in Otr. and Bov. $\mu \epsilon \lambda \epsilon \tau \hat{\omega}$

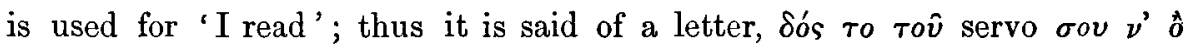

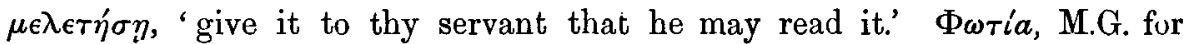
'fire,' is here used almost invariably in the sense of 'anguish.' Otr. $\sigma \omega \dot{\zeta} \zeta$,

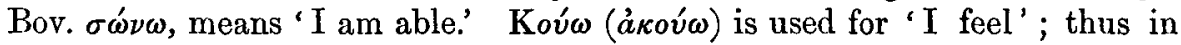

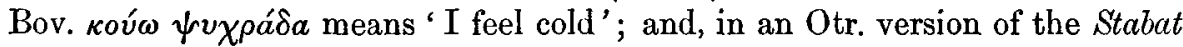

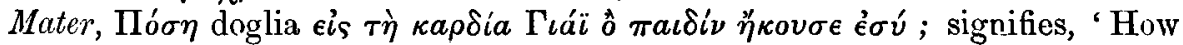
great sorrow did'st thou feel in thy heart for thy Son?'

\section{Peculiarities of the Dialect of the Terra d'Otranto.}

Sounds.-(1) The consonants $\kappa, \gamma, \tau, \delta, \beta, \nu$, are frequently lost between

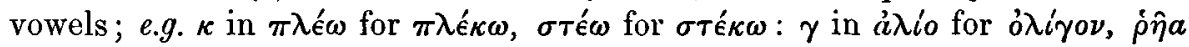

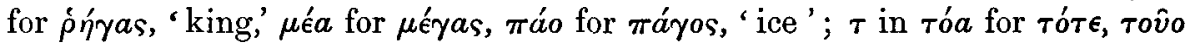

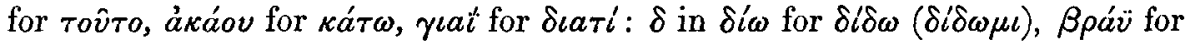

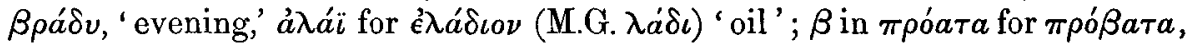

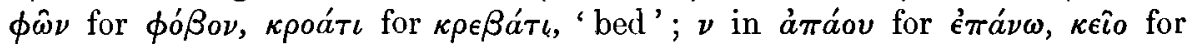

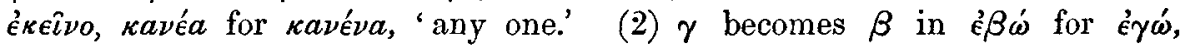

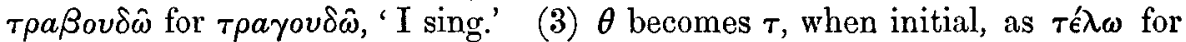

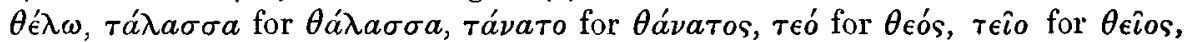
'uncle'; and also in various internal combinations, as $\hat{\eta} \rho \tau \epsilon$ for $\hat{\eta} \lambda \theta \epsilon, \pi \epsilon \tau \tau \epsilon \rho a ́$

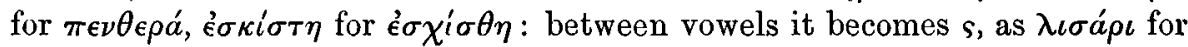

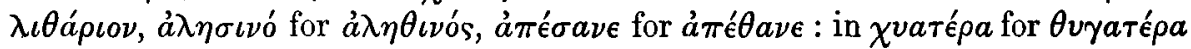


initial $\theta$ has become $\chi$. (4) The combination of $\phi$ with other consonants is of frequent occurrence; thus $\phi \sigma$ stands for $v \sigma$, as $\kappa \lambda a ́ \phi \sigma \omega$ for $\kappa \lambda a v ́ \sigma \omega$ : also

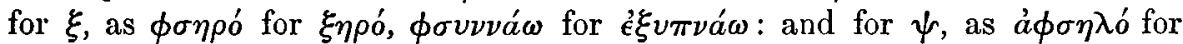
$\dot{v} \psi \eta \lambda \hat{o}^{\prime} \nu, \beta \lambda \epsilon ́ \phi \sigma \epsilon$ for $\beta \lambda \epsilon \epsilon \epsilon, \phi \sigma v \chi \chi^{\prime}$ for $\psi v \chi \chi^{\prime}$. Again, $\phi \tau$ stands for $\kappa \tau$, as

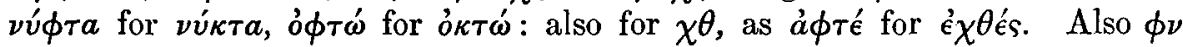
stands for $\kappa \nu$, as $\delta \epsilon i \phi \nu \omega$ for $\delta \epsilon i \kappa \nu \omega(\delta \epsilon i \kappa \nu \nu \mu \iota)$. (5) The loss of internal consonants has sometimes involved the loss of entire syllables, as $\mu a \lambda^{\prime} \eta$ for $\mu \epsilon \gamma a ́ \lambda \eta$,

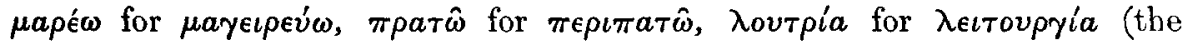
Eucharist).

INFLEXIONS.- In the verb $\epsilon i \mu i^{\prime}$ the forms most in use are pres. 3rd. sing.

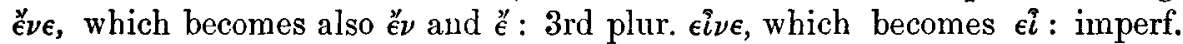

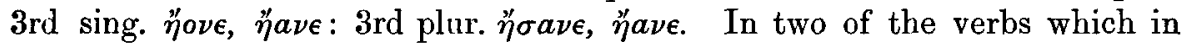
classical Greek form aor. 1 active in $-\kappa a$, that form has been retained both in

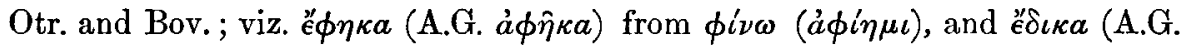
$\left.{ }^{\prime \prime} \delta \omega \kappa a\right)$ from $\delta i \delta \omega(\delta i \delta \omega \mu \iota)$; whereas in Greece they have become ä $\phi \eta \sigma a$, є $\delta \omega \sigma a$. It is probably on the analogy of these that in Otr. the aor. $\eta \ddot{v} \rho \eta \kappa a$ is

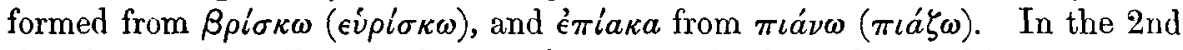
sing. imper. the $o$ (for ov) of aor. 1 is preserved where the word is proparoxy-

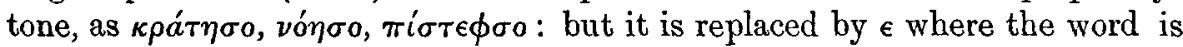

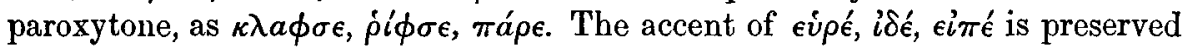
in the abbreviated forms $\beta \rho \epsilon$, ' look,' $\delta \epsilon$, ' see,' $\pi \epsilon \in$ ' 'say': in M.G. $\beta \rho \epsilon$ is used as an interjection, but in Bov. its plur. $\beta \rho \epsilon \epsilon \epsilon$ is found. The absolute use of an indeclinable verb-form as a substantive is not infrequent. as тò áya

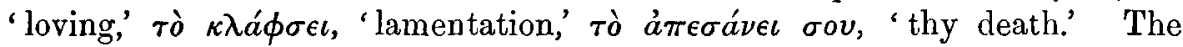
question of the origin of this usage cannot be dissociated from that of the

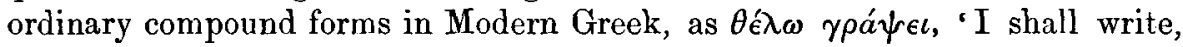

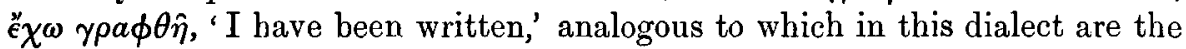

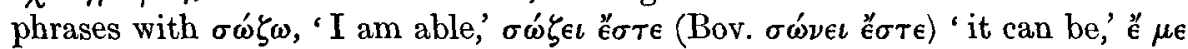
$\sigma \omega \zeta \epsilon \iota \delta \hat{\eta}$, 'you cannot see me.' Coray's view of the Modern Greek forms is that they are derived from the future infin., but M. Psichari, in his essay entitled Futur composé du Grec Moderne (p. 43), decides that the orthography of the termination throughout is $-\eta$, not $-\epsilon \iota$, and that it is derived from the aor. subj., the form of the 3rd pers. having been in the course of time used for the other persons. If, as I believe, this is the true view, then the substantival use of the verb in this dialect must be, not as Morosi thinks (Studi, p. 137), a survival of the infinitive, but a further adaptation of the fixed subjunctive form.

\section{Peculiarities of the Dialect of Bora.}

Sounds.- $\zeta$ (pronounced $d z$ ) frequently takes the place of $\xi$ and $\psi$ : as

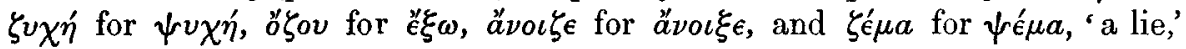
$\delta \iota \zeta a ́ \omega$ for $\delta \iota \psi a ́ \omega . \quad \theta$ almost always retains its original sound, whether at the beginning or in the middle of a word; but in a few instances, when initial, it becomes $\chi$, as $\chi a \rho \rho \hat{\omega}$ for $\theta a \rho \rho \hat{\omega}$, 'I believe,' $\chi \omega \rho \hat{\omega}$ for $\theta \omega \rho \hat{\omega}(\theta \epsilon \omega \rho \hat{\omega})$; and in $\phi \eta \lambda v \kappa \eta^{\prime}$ for $\theta \eta \lambda \nu \kappa \eta^{\prime}$ it becomes $\phi$. The combination $\sigma \tau$ is of very frequent

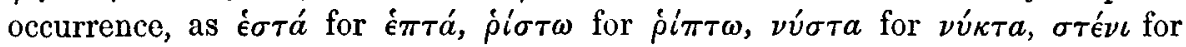




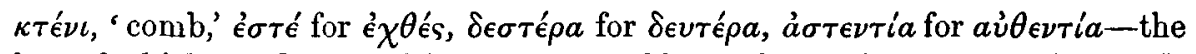

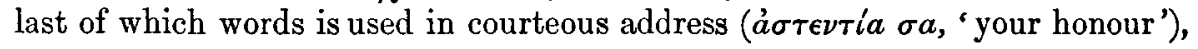

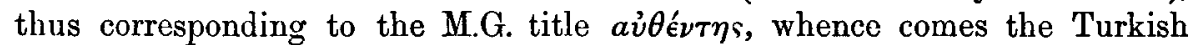
efendi. In these instances $\sigma \tau$ represents $\pi \tau, \kappa \tau, \chi \theta, v \tau, v \theta$; but in every case there was an intermediate sound $\phi \tau$, from which $\sigma \tau$ is derived.

INFLEXIONS.-In the verb, the classical form of the 3rd plur. pres., which is lost in M.G. and Otr., is here preserved ; e.g. from $\gamma \rho a ́ \phi \omega$, M.G. $\gamma \rho a ́ \phi o v \nu$ or

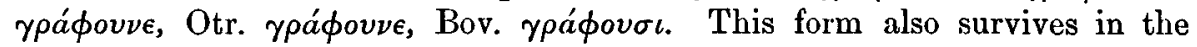
dialect of Siphnos, Naxos, and Santorin. ${ }^{1}$ In the same person of the aor.

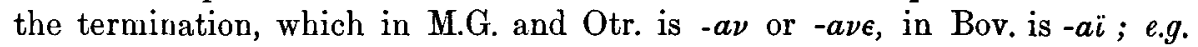

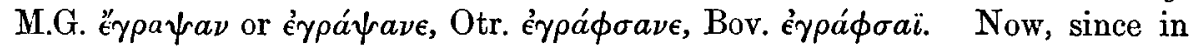
the islands just mentioned the same part of the verb is $-a \sigma \iota-a$ form which is found also in the language of the Mainotes in the south of the Morea, ${ }^{2}$ and in mediaeval Greek ${ }^{3}$-it is reasonable to suppose that the inflexion used at Bova is a corruption of this.

In speaking of the songs composed by these Italian Greeks, of which such extensive collections now exist, we may remark at starting that they bear no resemblance to the ballads and other popular poetry of modern Greece. This is the more remarkable because in every other region where Greeks are found-throughout the length and breadth of Greece, and in places as remote from one another as Cyprus, Samothrace, and Corsica-there are poems bearing the same features, and relating either to the same or to closely cognate subjects; nay, in some cases identical with one another, if allowance be made for differences produced by oral transmission. Here, however, we find no pastoral idylls, no stories turning on stirring incidents in war or brigandage, none which refer to the triumphs of Charon, the god of deaththemes which are of constant occurrence in the mother country. ${ }^{4}$ The long ballad metre, or political verse, in which the mediaeval Greek compositions, from the eleventh century onwards, were composed, and which is still the favourite measure in Greece, is unrepresented, except in a few fragments and distichs; nor is there any trace of the influence of the more elaborate rhyming metres, which in the course of the last four centuries the Greeks have borrowed from the Italians. The form of the poems on sacred subjects is derived from the religious songs of the Western Church, such as the Stabat Mater and Dies Irae, of both of which Italian Greek versions exist; in fact, these compositions probably are all either translations or adaptations. The longer of them comprise from twelve to thirty stanzas of four lines each either in iambic or trochaic metre, the second and fourth lines rhyming; and these lines are made up, sometimes of six or seven, sometimes of eight or nine syllables: but, in order that the metre of the verse may be preserved, it

\footnotetext{
1 Mullach, Grammatik der griechischen ${ }^{3} J . H . S$. vol. iv. p. 206.

Vulgarsprache, p. 92.

2 Bernhard Schmidt, Das Volkslcben der Neugriechen, p. 11.

4 For a further account of the Romaic ballads I may refer to a chapter on that subject in my Highlands of Turke?, vol, ii. pp. 224 foll.
} 
is often necessary that vowels should be elided, or syllables allowed to coalesce, in pronunciation. The love-songs-which form the bulk both of the Otranto and Bova collections, but in the latter district are almost the only existing kind of poetry-are usually composed of one or more stanzas of eight lines of ten or eleven syllables, in iambic metre. In these the rhymes are sometimes alternate throughout, but sometimes alternate in the first six lines, while the two last rhyme with one another. Some, however, are composed of six or of ten lines. The thoughts and sentiments which they contain, as well as their metrical form, correspond to those of the Italian love-songs of Apulia and Calabria, numerous specimens of which are given by Casetti and Imbriani in their Canti Popolari delle Provincie Meridionali; indeed, the amatory poems of Bova are for the most part imitations or paraphrases of these. To some extent the same thing is true of those of the Terra d'Otranto; but they possess much greater originality and variety, and are frequently shown to be the outcome of genuine feeling by their tender and impassioned expressions. Still, but few of them are devoid of some idea or phrase, the naïvete of which borders on bathos, so that it is difficult to select specimens which are thoroughly suitable for translation.

A third class of compositions, in addition to the religious and amatory poems, is formed by the dirges. These are made up of poetical similitudes and other commonplaces, many of which belong to a common stock, the inheritance of successive generations of professional mourners. They are sung over the bier during the interval between a person's death and his funeral, and the mode of proceeding on such an occasion-to judge from the account which Morosi has given ${ }^{1}$ - seems to correspond to what Fauriel ${ }^{2}$ and Mr. Bent ${ }^{3}$ have described as taking place in similar ceremonies in Greece. The idea that the custom is an inheritance from the mother country, though the songs themselves are not so, is confirmed by the word which is used in Greece

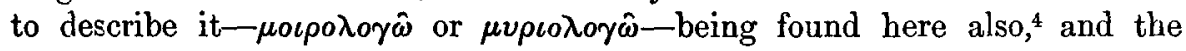
practice itself is unknown to the neighbouring Italians. These mourners are everywhere females; and at Sternatia, I was informed, there are still a few old women who sing these dirges at funerals. At Bova, however, the custom is unknown. They are supposed to be extemporised; and consequently, from the greater regularity of the metre of those which are given in Morosi's collection, we may conclude that we find them there in a somewhat more polished form than the original one. Frequently dialogues are introduced into them-between the wife and her dead husband, or the mother and her dead child; and sometimes Death is represented as interlocutor, as Charon is in the ballads in Greece. Some of these features will be traced in the following passage, which consists of three out of twelve stanzas of a mother's lament over her dead daughter.

\footnotetext{
1 Studi, pp. 93, 94.

- Chants Populaircs de la Grèce, vol. i. p. cxxxvii.
}

3 The Cyclades, pp. 217 foll.

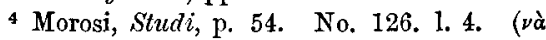

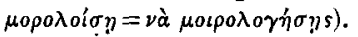




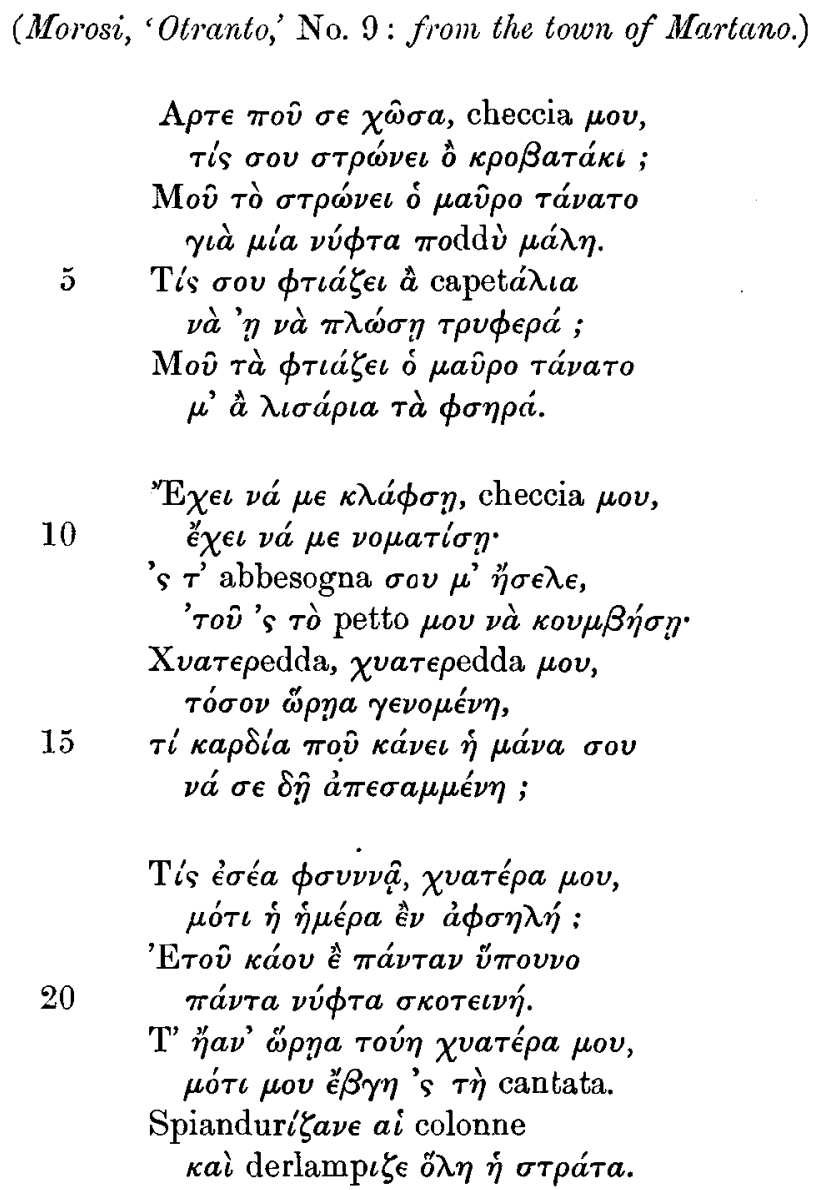

\section{Translation.}

'Now that they have buried thee, my darling, who will make thy little bed ?' 'My bed, dark Death makes it for me, for a long, long night.' 'Who will arrange thy pillows, that thou mayest be able to sleep softly?' 'Dark Death arranges them for me with the bare stones.'

'Thou must weep for me, my darling, thou must call me by my name; in thy troubles thou wert wont to desire me, that thou mightest lean here upon my breast. My dear daughter, my dear daughter, that wert so beautifully formed; what must thy mother's feelings be at seeing thee dead !

'Who will wake thee, my daughter, when the day is high?' 'Here below there is evermore sleep, evermore murky night.' 'How beautiful was this my daughter, when she went forth to the high mass! then the columns gleamed, and all the street was filled with light.' 


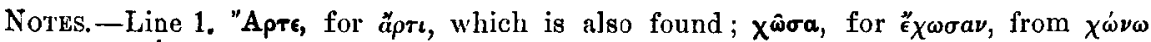
( $\chi \dot{\omega} \nu \nu v \mu \iota)$; checcia, a word not found either in M.G. or Italian; the meaning is 'little.'

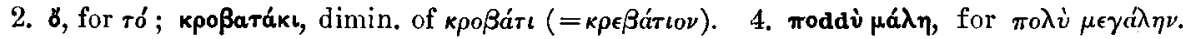

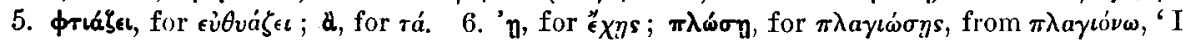

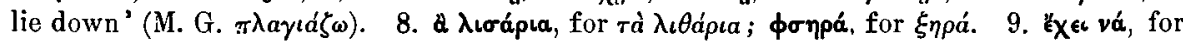

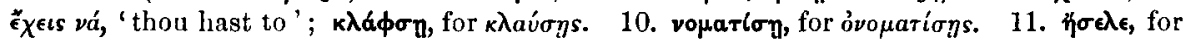

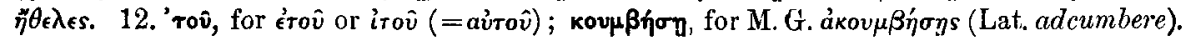

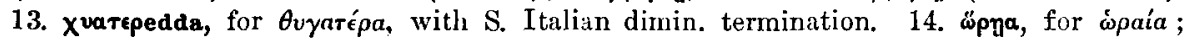

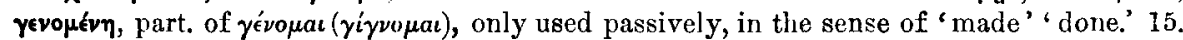

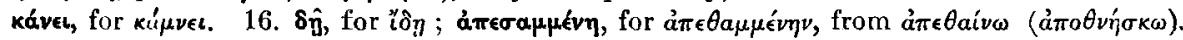

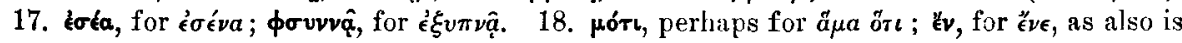

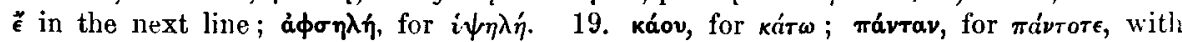

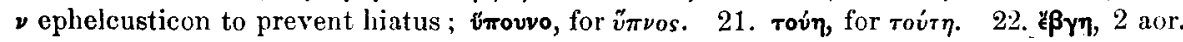

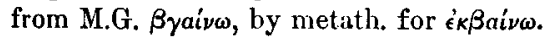

It is noticeable with regard to these dirges-and the same thing is true of those of Modern Greece ${ }^{1}$ - that the conception of death which they imply is purely pagan. In all of them the tomb is conceived of, not as a place of rest, but as a joyless abode, where the dead is oppressed by the gravestone that lies over him: there is no thought of a future state, or of rewards and punishments; the one prevailing feeling is that of regret for the loss of temporal enjoyments, which the departed has to suffer.

The specimens of the literature of these Greeks of South Italy which I subjoin consist of five poems and one story from the Terra d'Otranto, and two poems, some verses of a translation of the story of Joseph and his brethren, and a number of proverbs from the district of Bova. The former of these sets, which is by far the more important, contains one sacred song, two relating to the subject of love, and two others in a lighter vein; the latter comprises one love-poem, and another on the subject of the redbreast. As these compositions have been transmitted orally by the people who possess them, without being committed to writing, it was natural that those who collected them should write them down phonetically in Roman characters; and Professors Morosi and Pellegrini, with whom linguistic accuracy was rightly the first consideration, have printed them thus in their publications. Still, it seems a little hard that the Greek language, wherever found, and however corrupted, should not be written in Greek; and for this reason, and still more because the difficulty of understanding the words is increased twofold by the unfamiliarity of their appearance in a Roman dress, I have transcribed than in Greek characters. I have also in each case added an English translation, either in prose or verse, and notes to explain the peculiar forms of the words, though I am obliged to assume that my readers possess an elementary knowledge of Modern Greek. By this means, and by the aid of the hints on the language already given, I trust that these specimens may become intelligible. It will be observed that Italian words are occasionally interspersed among the Greek ones; this has arisen in some cases from their having been permanently embodied in the language; but more often, in all

1 Sec my remarks on this subject in Highlands of Turkey, vol, ii. p. 323. 
probability, it has been the result of substitution in the course of singing, when the original word has been forgotten. The process has gone further in the Bova songs than in the others; and in some of these the Italian words seem to have been purposely introduced, for in one we find Italian rhymes alternating with Greek ones, in another all the rhyming words are Italian, and in a third the entire lines are alternately Greek and Italian. ${ }^{1}$

Specimens of the Poems \&c. of the Terra d'Otranto.

I.

A Lament at the Tomb of Christ.

(Morosi, 'Otranto,' No. 95 : from Corigliano.)

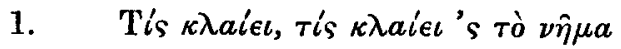

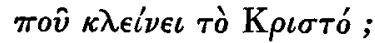

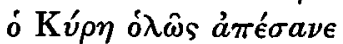

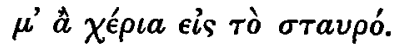

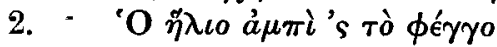

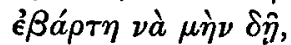

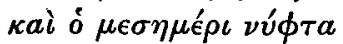

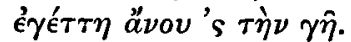

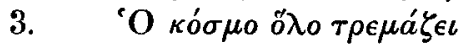

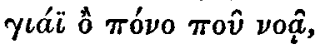

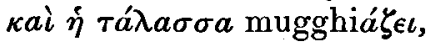

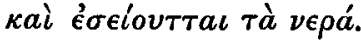

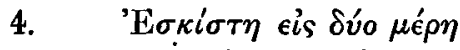

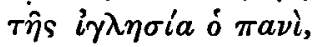

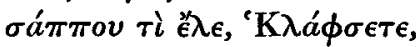

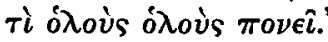

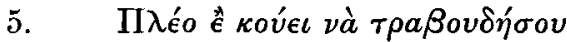

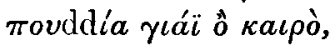
$\pi \circ \hat{v} i \kappa a ́ \nu \epsilon \iota$ Tó $\sigma o \nu$ ă $\sigma \chi \eta \mu o$,

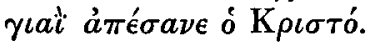

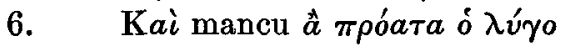

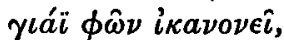

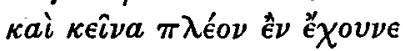
$\delta \dot{\epsilon} \chi \chi^{\prime} \rho \tau a \delta \dot{~} \mu a \nu \delta \rho i ́$.

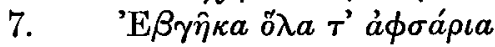

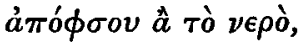

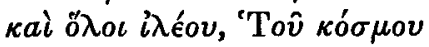

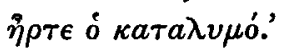

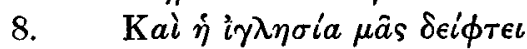

1 Comparetti, Saggi, Nos. 21, 18, 33. 


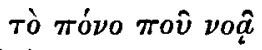

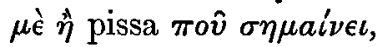

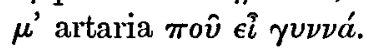

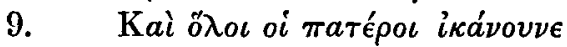

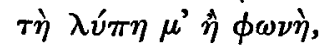

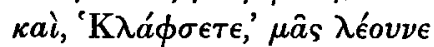

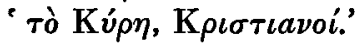

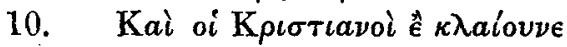

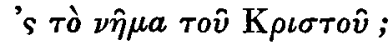

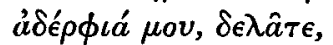

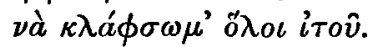

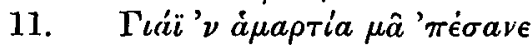

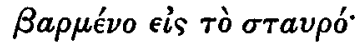

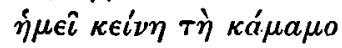

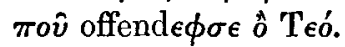

12. Kai $\dot{\eta} \mu a ́ \nu a \dot{\eta} \pi o \nu \eta \mu e ́ \nu \eta$

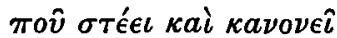

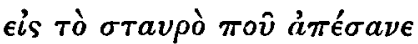

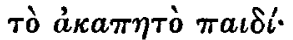

13. $\Sigma a ́ \pi \pi o v \tau i \mu h a ̂ s \phi \omega v a ́ \zeta \epsilon \iota$

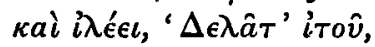

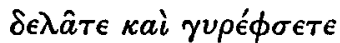
$\phi \sigma \iota \chi \omega ́ \rho \eta ~ \tau o \hat{~ T є o ̂ े . ' ~}$

14. $\Phi \sigma \iota \chi \omega ́ \rho \eta \sigma \iota \phi \sigma \iota \chi \omega ́ \rho \eta \sigma \iota$ $\gamma \nu \rho \in ́ \omega \mu \epsilon, \mathrm{K} \rho \iota \sigma \tau \iota a \nu o i$,

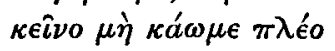

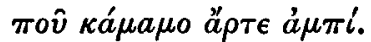

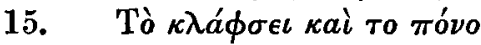

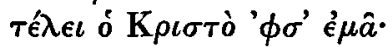

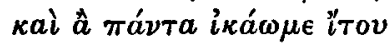
$\mu \hat{a} s \delta \epsilon \hat{\imath}$ ' $\nu$ eternità.

\section{Translation.}

1. Who weeps, who weeps at the sepulchre which encloses Christ? The Lord of all has died with his hands upon the cross.

2. The sun hid (lit. placed) itself behind the moon that it might not see, and the midday became night over the earth.

3. The whole universe shudders from the suffering that it feels, and the sea roars, and its waters are agitated.

4. The vail of the temple was rent in twain, as though it said, 'Lament, for all are afflicted.'

5. No longer can you hear the birds sing because of the sky, which is so overcast (lit. the weather which is so bad) since Christ is dead.

6. And from terror not even does the wolf regard the sheep; and they no longer have either pasture or a fold. 
7. All the fishes came forth from the water, and all men say, 'The dissolution of the universe has arrived.'

8. And the Church declares to us the suffering that it feels, by the pyx which gives a sound (from being empty), by the altars which are bare.

9. And all the priests express their sorrow with their voices, and say to us, 'Christians, lament the Lord.'

10. And shall not Christians lament at the sepulchre of Christ? Come, my brethren, that we may all lament here.

11. For our sin he died, fixed on the cross; it was we who committed that sin which offended God.

12. And lo, the suffering mother, who stands and looks at the cross, on which her beloved Son died:

13. Even as if she called to us and said, 'Come hither, come and seek forgiveness from God.'

14. Forgiveness, forgiveness, ye Christians, let us seek; let us do no more what we have done hitherto.

15. Lamentation and affliction is what Christ desires of us; and if we act always thus, he will bestow on us eternity.

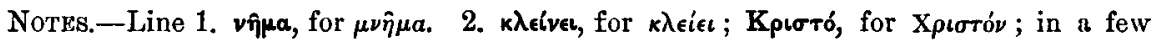
words, of which this and $\vec{\epsilon} \rho \chi o \mu a l$ are the most important, the aspiration of $\chi$ is lost. 3 .

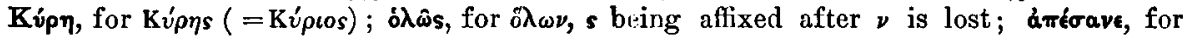

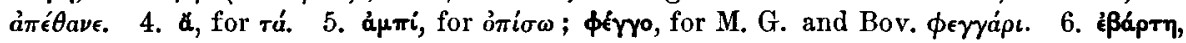

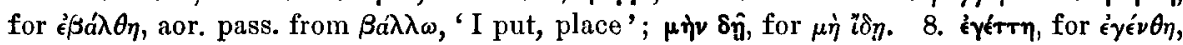

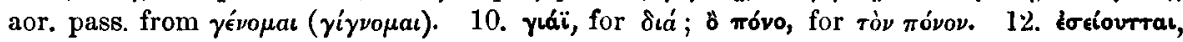

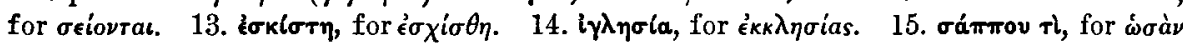

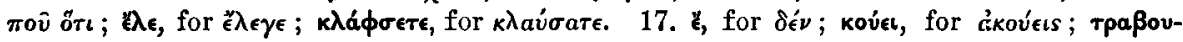

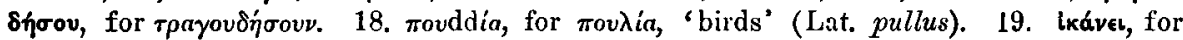

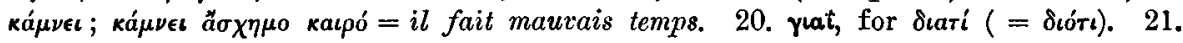

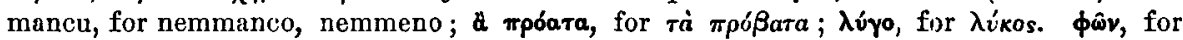

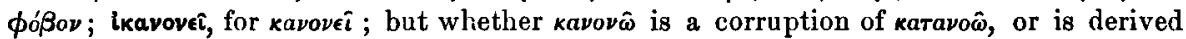

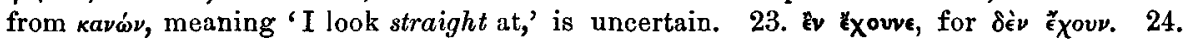

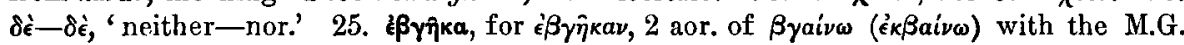

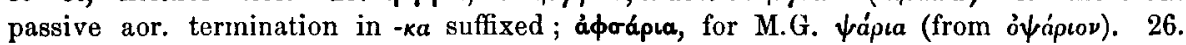

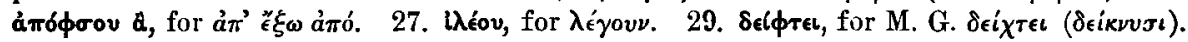

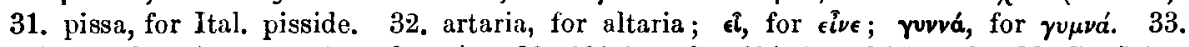

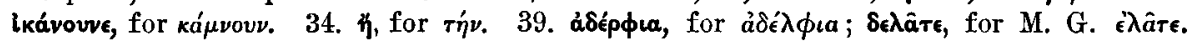

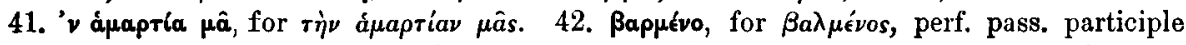

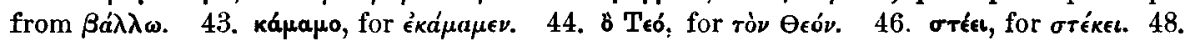

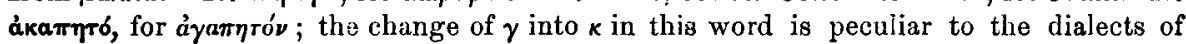

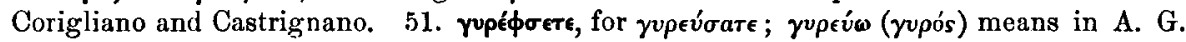
'I go round,' in M. G. 'I go round, look round, seek for.' 52 . $\phi \sigma \cdot \mathbf{x}^{\omega} \omega \eta \eta$, an abbreviation

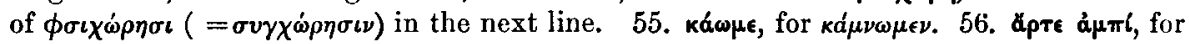

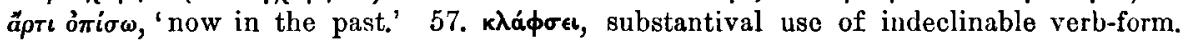

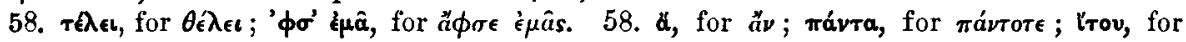

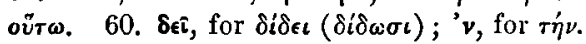


II.

The Dying Lover's InJunctions.

(Morosi, 'Otranto,' No. 80 : from Calimera.)

"A

escappeddata $\mu \dot{\varepsilon} \sigma a$ 's $\tau \grave{\eta} \nu a \grave{\nu} \lambda \grave{\eta}$,

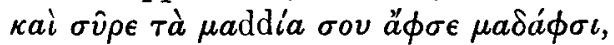

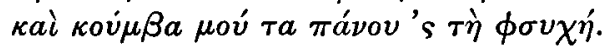

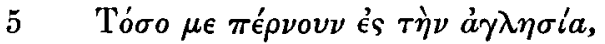

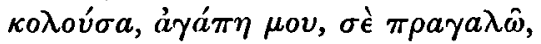

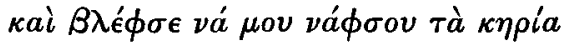

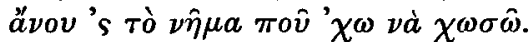

10

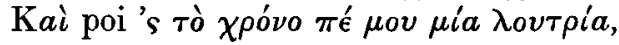

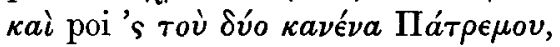

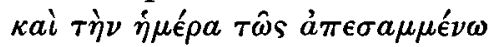

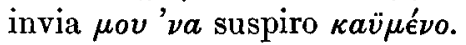

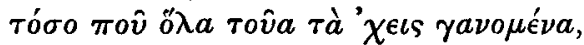

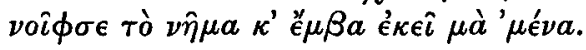

\section{Translation.}

Love, when I die, I will that thou bewail me

Down in the court-yard with uncover'd head,

And with the mantle of thy tresses vail me

Over my heart in silken folds outspread.

5 When to the holy Church my corpse they carry,

I pray thee follow in the mourners' line,

And o'er the grave, where thy true love they bury,

See that the funeral tapers duly shine.

10 And after two years chant a litany ;

And when the Spirits are commemorated

Breathe burning sighs in memory of me.

When these kind offices accomplished are,

Open the tomb, and come my grave to share.

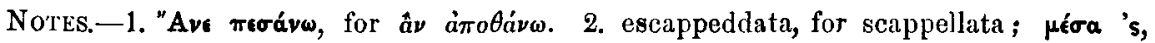

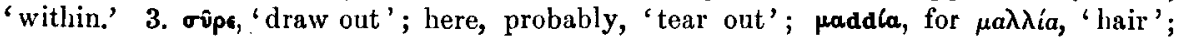

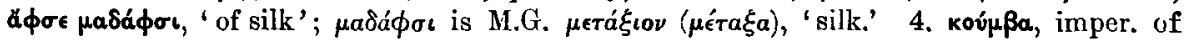

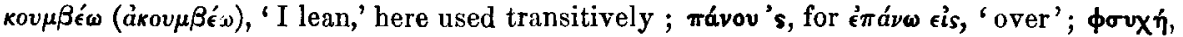

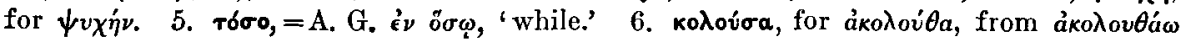

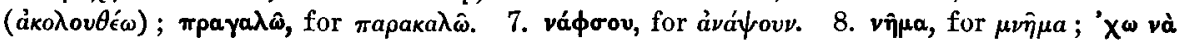

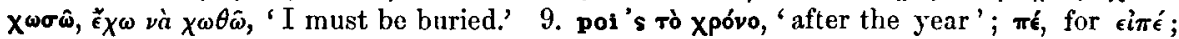

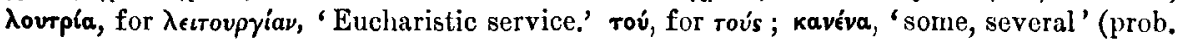




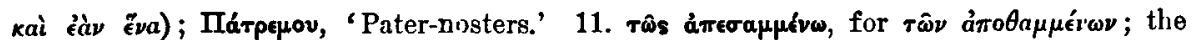

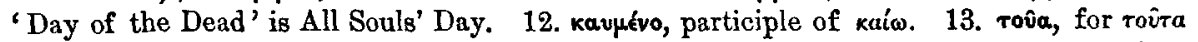

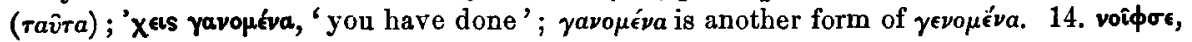
for ẩ $\nu o \iota \xi_{\epsilon} ; \mu \hat{\alpha}$, for $\mu \epsilon^{\epsilon}$, ' with.'

III.

The Deserted Lover's Imprecatton.

(Morosi, 'Otranto,' No. 119 : from.Corigliano.)

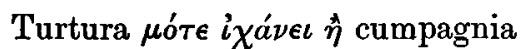

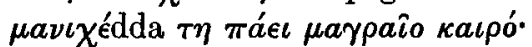

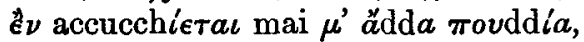

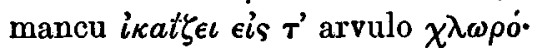

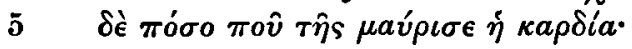

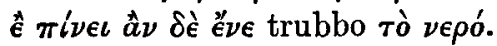

'O K

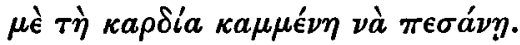

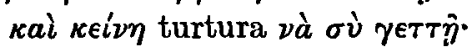

10

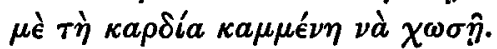

\section{Translation.}

The dove that is deserted by her mate

In solitude abides the live-long day;

Far from her fellows dwells she desolate,

Nor even perches on the verdant spray:

5 See how her soul is darkened by her fate!

In turbid streams her thirst she doth allay.

Like that sad bird may Christ the righteous make thee;

With heart all flame may Death the avenger take thee;

Like that sad bird distraught may'st thou become;

With heart all flame descend into the tomb.

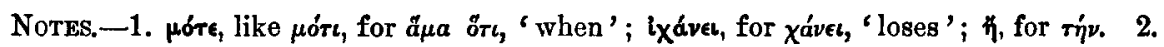

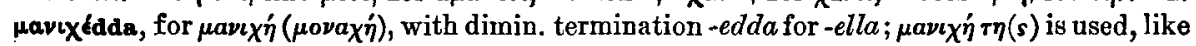

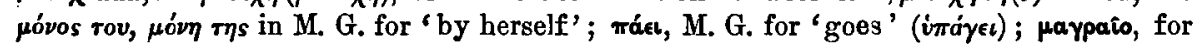

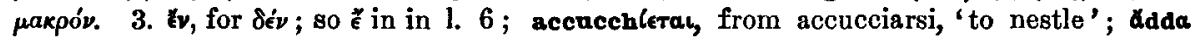

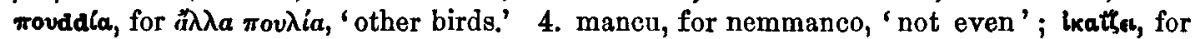

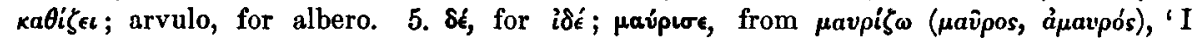

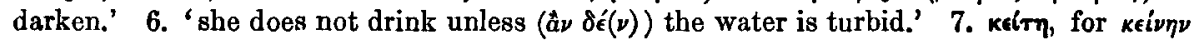

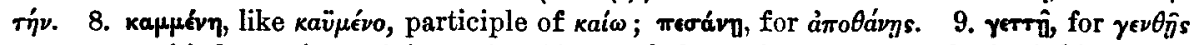

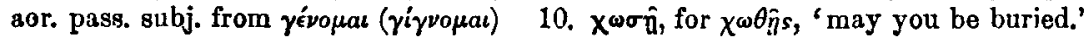


IV.

Advice to Young Men Intending to Marky.

(Morosi, 'Otranto,' No. 120 : from Corigliano.)

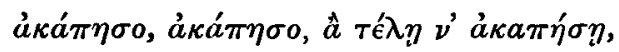

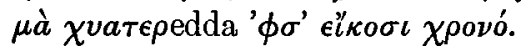

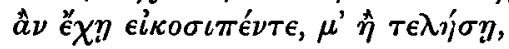

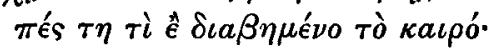

5

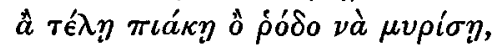

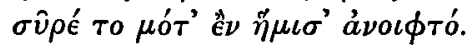

Translation.

If you would wed, then choose

A maid of twenty years :

At twenty-five, refuse,

Say she too old appears :

5 Half-blown he culls the rose,

Who for its fragrance cares.

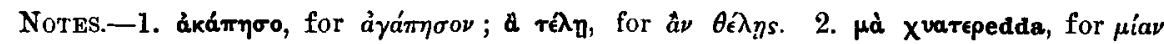

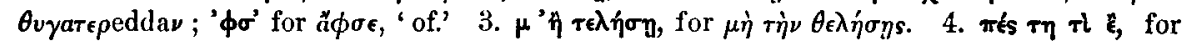

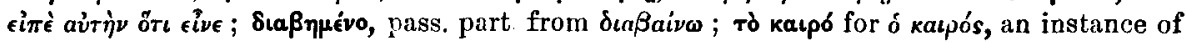

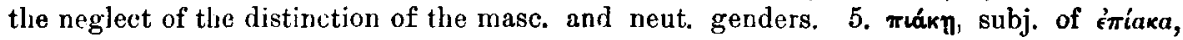

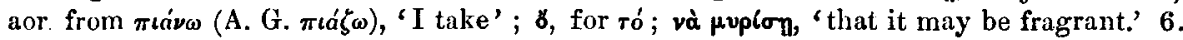
бîpe, 'draw' 'pluck'; ávoıфtó, for ảvockróv.

\section{V.}

The Son-In-Law's Complaint.

(Morosi, 'Otranto,' No. 94: from Castrignano.)

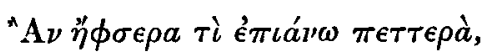

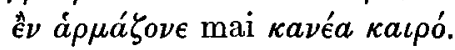

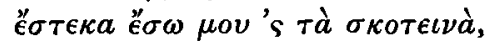

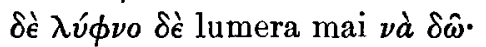

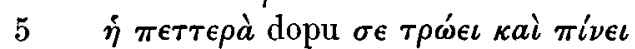

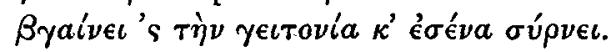

\section{Translation.}

If I had known that (in marrying) I was taking to me a mother-in-law -I would never have married under any circumstances:-I would have stopped at home in the dark-so as never to see either lamp or fire.-Your mother-in-law after eating and drinking at your expense-goes out among the neighbours and maligns you. 


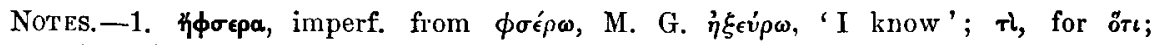

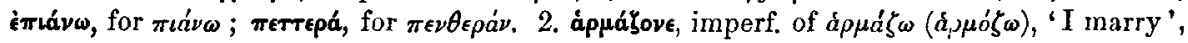

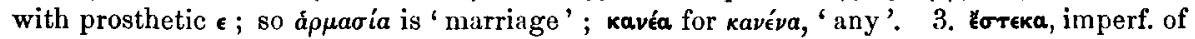

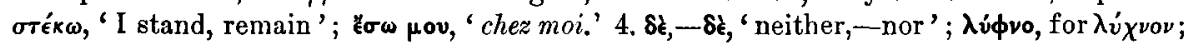

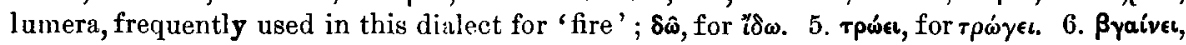

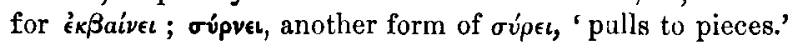

\section{VI.}

STORY OF THE wOMaN Who PRAYED FOR THE King.

$$
\text { (Morosi, 'Otranto,' p. } 73 \text { : from Martano.) }
$$

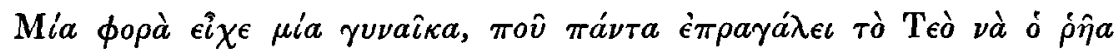

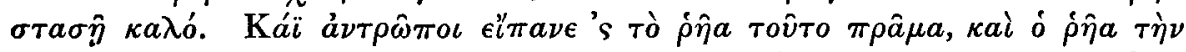

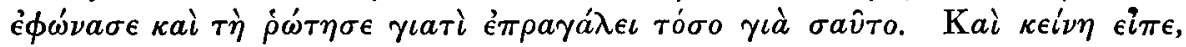

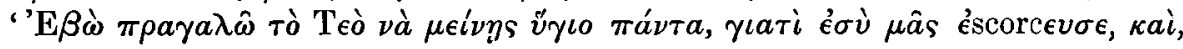

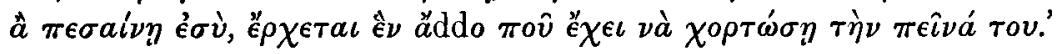

\section{Translation.}

There was once a woman, who prayed to God continually that the king might keep in good health. Certain men reported this matter to the king, so the king summoned her, and asked her why she prayed so much for him And she said, 'I pray God that you may continue in life for ever, because you have flayed us, and, if you die, another will come who will have to satisfy his hunger.'

Notes. Mia фopá, the M. G. expression for 'once'; in Bov. ẽva viaggio is used, 'viaggio' for 'volta' being common in the S. Italian dialects ; eíx€, for the phrase cp. Fr. il $y$ a,

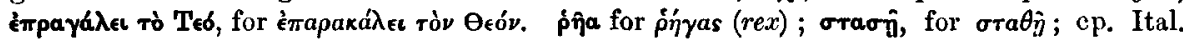
star bene. Kái, for M. G. kárı (perhaps kaì éáy $\tau i$ ) 'some,' 'some or other'; ipâua, for

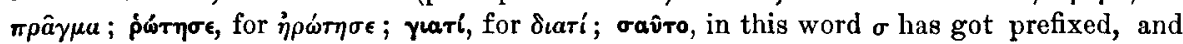

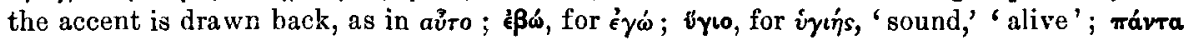

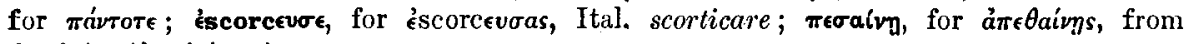
$\dot{a} \pi \epsilon \theta a i v \omega(\dot{a} \pi 0 \theta \nu \dot{\eta} \sigma \kappa \omega)$.

Specimens of the poems \&c. of the district of Bova.

I.

\section{Good Night.}

(Morosi, 'Bova,' No. 34; cp. Pellegrini, No. 40, and Comparetti, No. 29.)

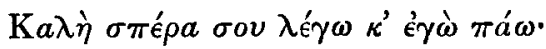

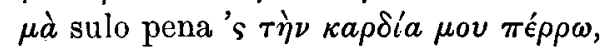

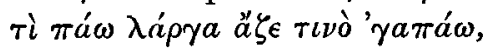




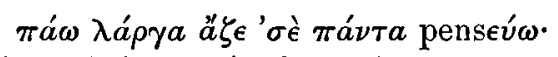

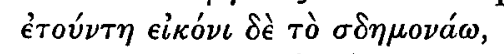

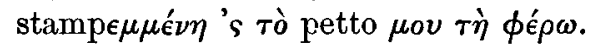

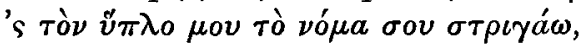

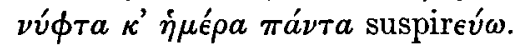

\section{Translation.}

Thus bidding thee 'Good Night' I go my way;

Yet naught but sorrow in my heart I bear-

Grief, that from her I love afar I stray,

Afar from thee who art my constant care :

$5 \quad$ Stamped on my heart thy image dwells alway;

That vision from my memory ne'er can fall :

I ever sigh for thee by night and day;

E'en in my sleep upon thy name I call.

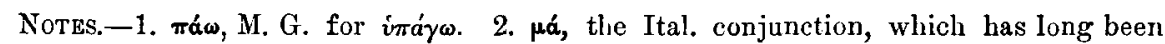

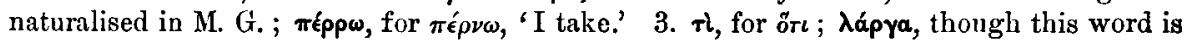

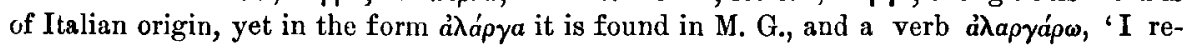
move', is derived from it; $\alpha \xi_{\epsilon}$, the same as Otr. ä $\phi \sigma \epsilon$, 'from'; $\tau \iota v \delta$, a form used for the

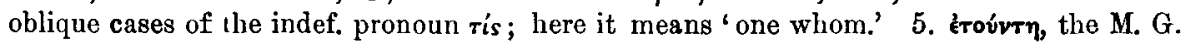

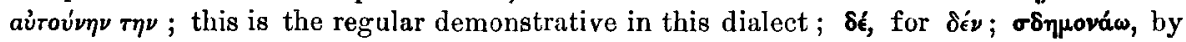

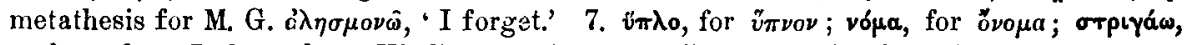
perhaps from Ital. stridere; Kind's Lex. gives a M. G. form $\sigma \tau \rho i \zeta \omega$ for $\tau \rho i \zeta \omega$.

II.

The Fate of the Redbreast.

(Morosi, 'Bova,' No. 38 ; cp. Pellegrini, No. 10.)

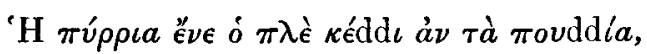

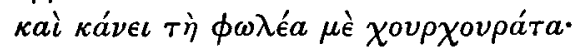

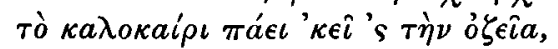

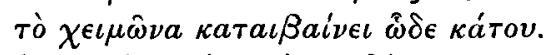

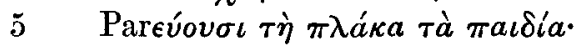

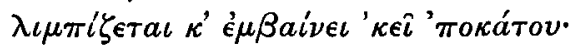

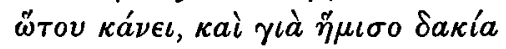

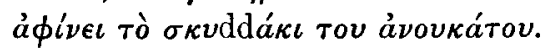

\section{Translation.}

The redbreast is the smallest bird that flies ;

He builds his little nest with tufts of hay:

In summer-time he to the mountain hies,

In winter he comes down with us to stay. 
5 The children to entrap him springes make;

$\mathrm{He}$ is enticed, and enters in beneath.

Poor fool ! and for a sorry morsel's sake

His neck is twisted and he meets his death.

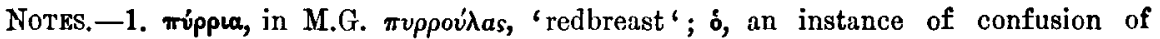

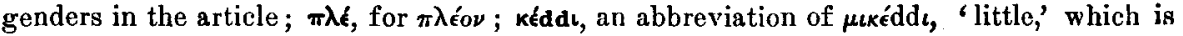

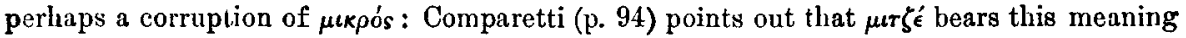
in the Tzaconian dialect in the Peloponnese, and $\mu \iota \tau \zeta \eta \bar{s}$ in the dialect of Cyprus ; áv ; this is the form which ảmó regularly takes with the article in Bov. 2. xáve, for xápuet, 'makes ;'

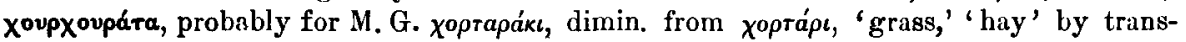

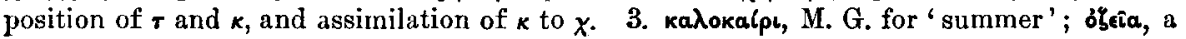

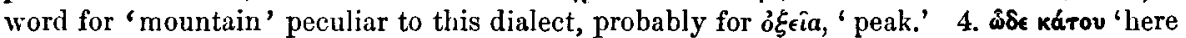

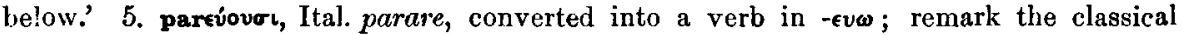

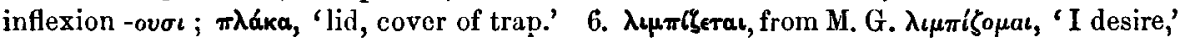

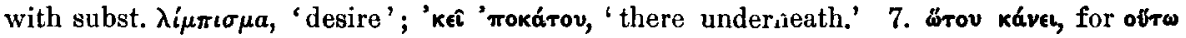

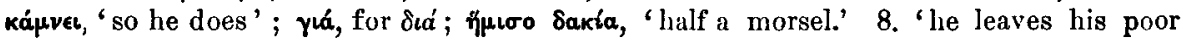

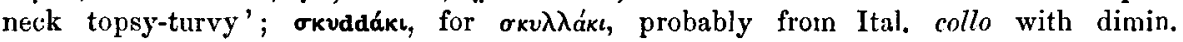
termination.

Genesis XLV. 1 -6.

(Pellegrini, pp. 118, 119.)

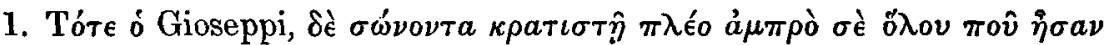

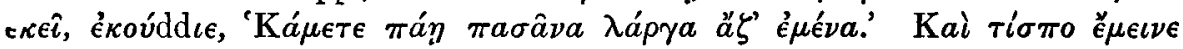

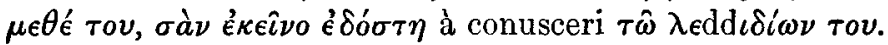

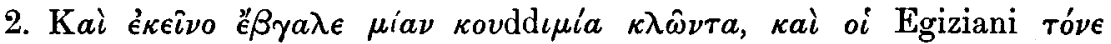

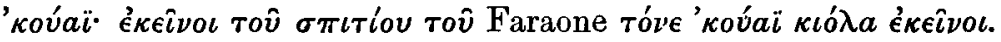

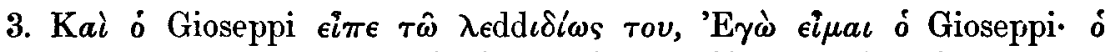

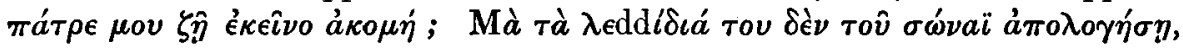

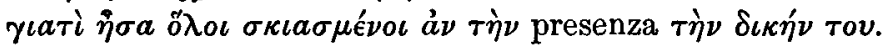

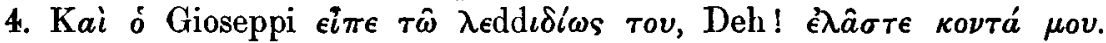

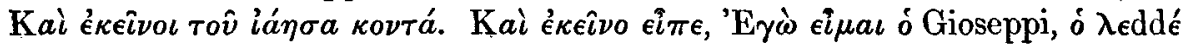

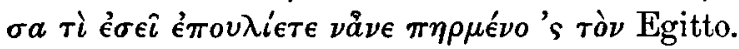

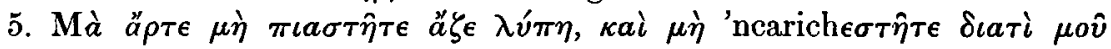

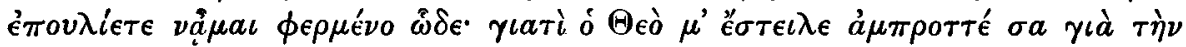
iүı⿻ía $\sigma a$.

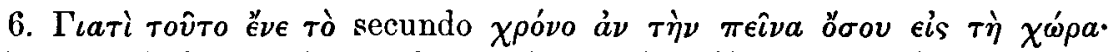

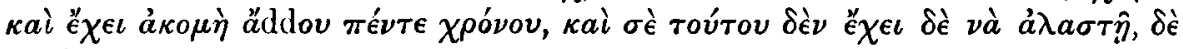
$\nu \grave{a} \theta \epsilon \rho \iota \tau \hat{\eta}$.

\section{Translation.}

1. Then Joseph, not being able to command himself longer before all who were there, cried, Make every one to go out from me. And no one remained with him, while he made himself known to his brethren.

2. And he uttered a cry weeping, and the Egyptians heard him; those of the house of Pharaoh, they also heard him. 
3. And Joseph said to his brethren, I am Joseph; my father, doth he yet live? But his brethren were not able to answer him, for they were all afraid at his presence.

4. And Joseph said to his brethren, Pray, come near to me. And they came near to him. And he said, I am Joseph, your brother whom ye sold to be taken to Egypt.

5. But now, be not seized by grief, and be not burdened because ye sold me to be brought hither; because God sent me before you for your welfare.

6. Because this is the second year of the famine in the land, and there are yet five years, and in these there will not be either ploughing or harvest.

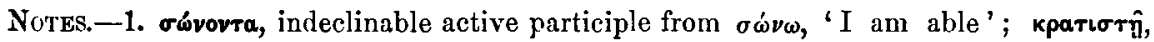

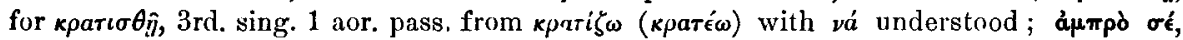

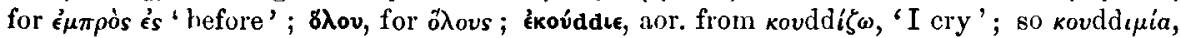

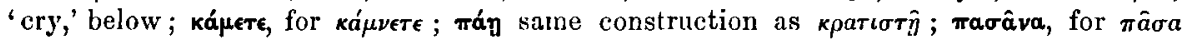

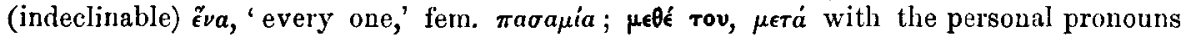

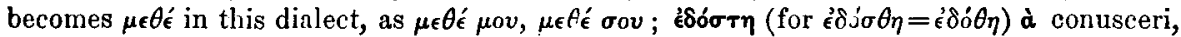
'gave himself to be known'; $\tau \hat{\omega}$, for $\tau \hat{\omega} \nu ; \lambda \epsilon d a \iota \delta i \omega \nu$, plur. of $\lambda \epsilon \mathbf{d d} \dot{\epsilon}$, which, whatever its derivation, takes the place of áo€ $\lambda \phi o^{\prime}$ in this dialect.

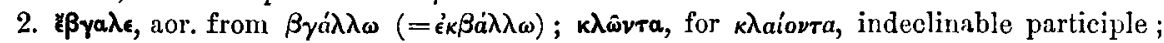

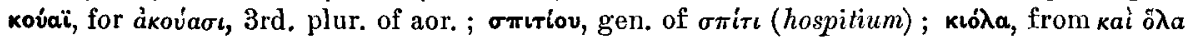
'withal'; in M. G. usually in the sense of 'for all that,' ' notwithstanding.'

3. $\lambda \in d d \iota \delta(\omega s$, the gen. plur. terminations in $-\omega s$ and $-\omega \nu$ are equally found ; ákopr, M. G.

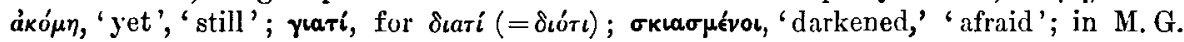

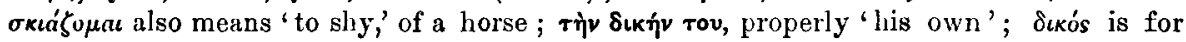
cióckós, ' proprius.'

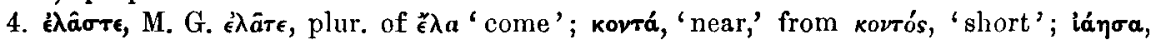
for $(\dot{\boldsymbol{\delta}} \delta)_{\iota} \dot{\alpha}(\beta) \eta \sigma a(\nu)$ from $\delta a \beta a i \nu \omega$, ' passed,' 'presented themselves '; $\sigma \alpha$, for $\sigma a s$ enclitic ; $\tau i$,

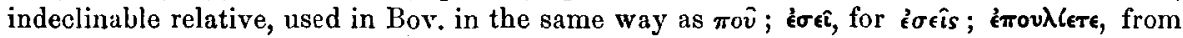

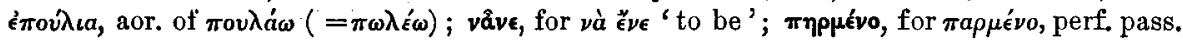
part. from $\pi \dot{p} \rho \nu \omega$, 'I tuke.'

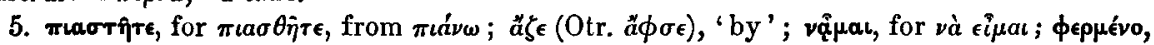

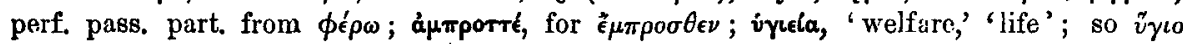
'alive.'

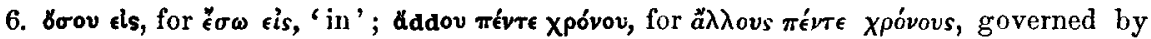

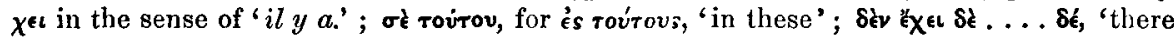

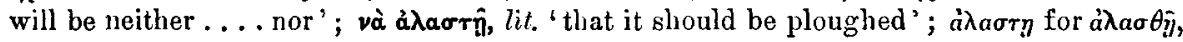

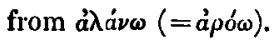

\section{Proverbs.}

(Morosi, 'Bova,' Nos. 75, 23, 30, 41, 120, 116, 53, 105.)

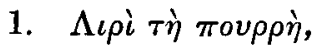

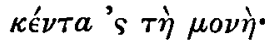
$\lambda \iota \rho \grave{~ \tau \eta े ~ \beta \rho a \delta i ́ a, ~}$

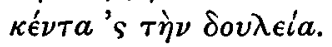

'A rainbow in the morning,--hasten to your dwelling:-A rainbow in the evening,--hasten to your work.' 


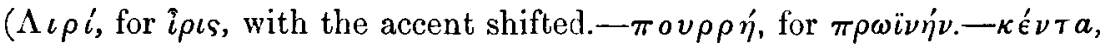
'spur, hasten,' from $\kappa \epsilon \nu \tau a ́ \omega(\kappa \epsilon \nu \tau \varepsilon ́ \omega) .-\beta \rho a \delta i a$, M. G. $\beta \rho a ́ \delta v$.)

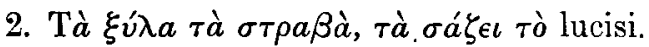

'Bent timbers are straightened by the fire.'

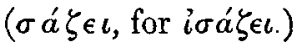

3. 'O $\sigma \kappa u ́ d d o ~ \pi o \hat{v} \delta \dot{\nu} \nu a ̉ \lambda \epsilon \sigma \tau a ́ \epsilon \iota ~ \delta a \gamma \kappa a ́ \nu \epsilon \iota \kappa \rho v \phi a ́$.

'The dog that does not bark bites stealthily.'

( $\mathrm{O} \sigma \kappa v \mathrm{ddl}, \mathrm{M}$. G. тò $\sigma \kappa v \lambda i$, but $\dot{o} \sigma \kappa v \dot{\lambda}$ os is found in mediaeval Greek, and in Hesych.- $a \dot{\lambda} \epsilon \sigma \tau a \dot{\epsilon} \epsilon \iota$, for $\dot{v} \lambda a \kappa \tau \epsilon \hat{\imath}$.)

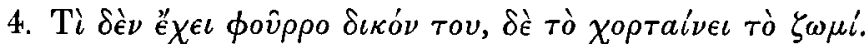

'If a man has no oven of his own, his bread does not satisfy him. $\psi \omega \mu i$.)

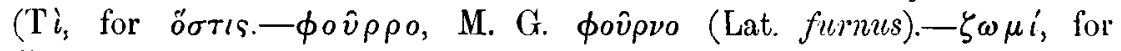

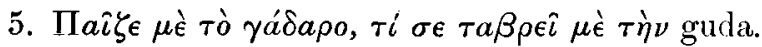

'Play with an ass, and he'll hit you with his tail.'

( $\gamma a$ á $a \rho o$, M. G. for 'ass,' more correctly yaî́ $a \rho o .-\tau a \beta \rho \epsilon \hat{\imath}$, by metathesis for $\tau \rho a \beta a \hat{a}$, ' pull,' 'strike.'-guda for coda.)

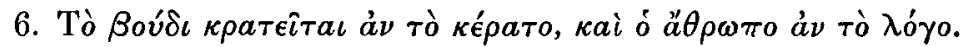

'An ox must be held by his horns, and a man by his word.'

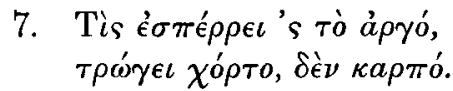

' He that sows untilled land, will eat grass instead of corn.'

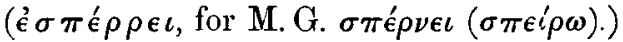

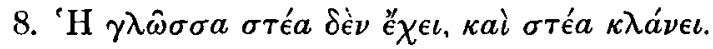

' Though the tongue has no bones, it can break bones.'

$\left(\sigma \tau \epsilon \dot{\epsilon} a\right.$, for ó $\sigma \tau \tau^{\prime} a .-\kappa \lambda a^{\prime} \nu \epsilon \iota$, for $\left.\kappa \lambda a ́ \epsilon \iota.\right)$

It remains now to investigate the evidence which is funished by the language, and by historical documents, with regard to the time at which these Greeks settled in southern Italy. We have already seen that, at an early stage in the enquiry respecting the language, Prof. Pott showed that it is Modern Greek, and not a dialect derived independently from the ancient language; and this, I think, will have been clear to any one who has examined the specimeus which have been given above. But it may perhaps be worth while to enumerate a few out of the very numerous words and phrases, in which the correspondence with the one, and the contrast with the other, is unmistakable. Among familiar substantives we find (allowing in some instances for a slight difference of form from Modern Greek) - for 'water,' not $\ddot{v} \delta \omega \rho$, but $\nu \epsilon \rho o ́$; for ' wine,' not oivos, but $\kappa \rho a \sigma l$; for 'bread,' not ápros,

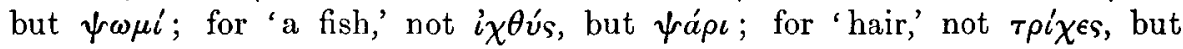

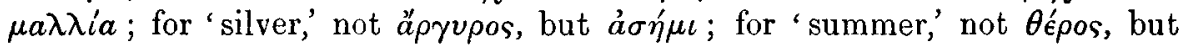

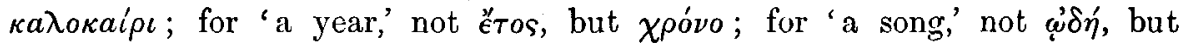

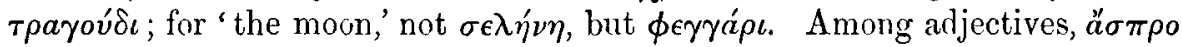


lias taken the place of $\lambda \epsilon v \kappa o ́ s, \mu a \hat{v} \rho o$ of $\mu e^{\lambda} \lambda a \varsigma, \chi o \nu \delta \rho o ́$ of $\pi a \chi u ́ s, \kappa \iota \nu o u ́ \rho \iota$

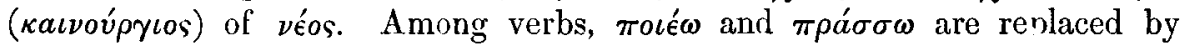

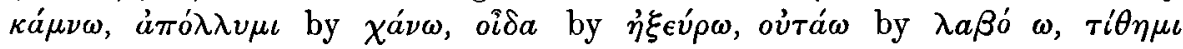
by $\beta a \dot{a} \lambda \lambda \omega$. The same thing is even more clearly seen in phiases, such

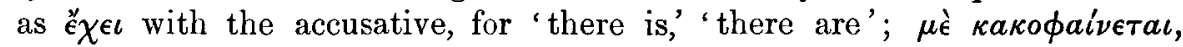

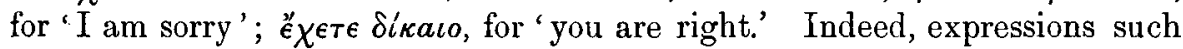
as these are so modern in their aspect, as to tempt us to believe that they belong to a recent stage in the development of Modern Greek; but this again would probably be a rash conclusion, for the more we study the mediaeval Greek poems and documents, the more we are struck with the modern character of the diction which they employ. Anylow, it is possible to show by several different lines of proof, that the Greek which is spoken in Italy separated off at a comparatively early period from the language of the mother country; and to this point in the argument we will next proceed.

In the first place, there are not a few classical wor:ls, which are retained either in the Terra d'Otranto, or in the Bova district, or in both dialects, while they are lost, or have become quite unfamiliar, in Greece. A striking instance of this is found in the adverb of time 'now.' In Ancient Greek this

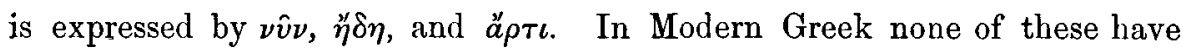
survived, and their place is taken by $\tau \dot{\omega} \rho a$, i.e. (av) $\tau \hat{\eta} \tilde{\omega} \rho a$. . But in Italy $\nu \hat{v} \nu$ and $\eta \delta \eta$ on the one hand, and $\tau \omega \rho \rho a$ on the other, are unknown, and ä $\rho \tau \iota$ or

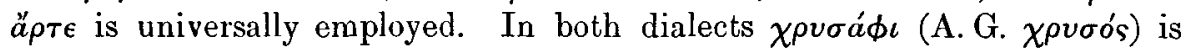

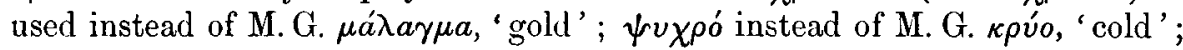
$\kappa \lambda a ́ \omega$ (Otr.) and $\kappa \lambda a ́ \nu \omega$ (Bov.). instead of M. G. $\tau \zeta a \kappa i \zeta \omega$, 'I break'; $\sigma \omega \zeta \omega$ (Otr.) and $\sigma \dot{\omega} \nu \omega$ (Bov.) instead of M. G. $\dot{\eta} \mu \pi \circ \rho \hat{\omega}$, 'I am able'; $\dot{\rho} \iota \hat{\omega}$ (Otr.) and

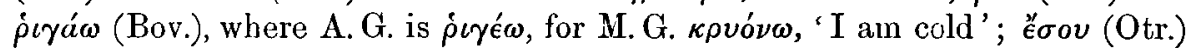

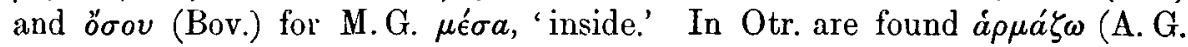

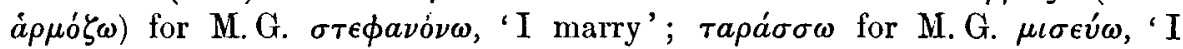

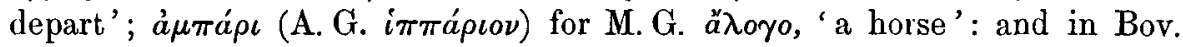

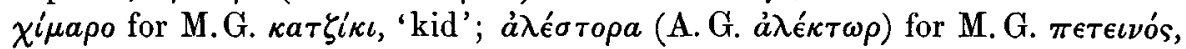

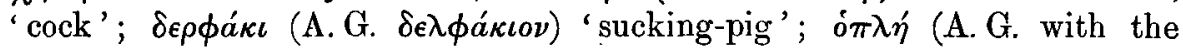

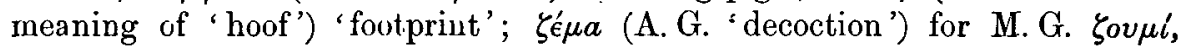

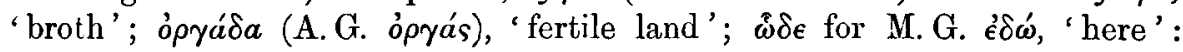
$\mu \epsilon \tau a \pi a ́ \lambda \epsilon$ also ( $\mu \epsilon \tau a \grave{a} \pi a ́ \lambda \iota \nu)$, 'once more,' has an ancient character. To these we may add certain words, the original form of which is found here, while

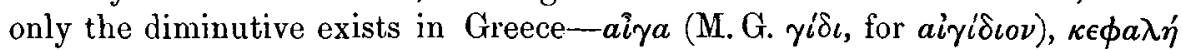

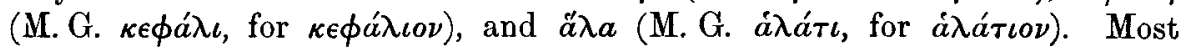
remarkable of all is the termination of the $3 \mathrm{rd}$ plur. of the present tense of

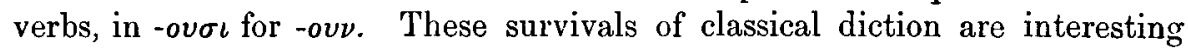
in themselves, and serve also to prove the primitive character of these dialects.

Further; the numerous differences of usage which exist between the Greek that is spoken in Italy and ordinary Modern Greek imply that the two have long been separated. Among these the following are the most noticeable. In Greece the forms of affirmation and negation are $\nu a i$ or $\mu a \lambda_{\iota} \sigma \tau a$, and $o$ $\chi \iota$; in Italy nonc of these are found, but 'yes' is expressed in Otr. by 
ov $\mu \mu \epsilon$, in Bov. by $\mu a \nu a i$ ', and 'no' in Otr. by $\delta$ '́ $\gamma \epsilon$ (pronounced deghe), in Bov.

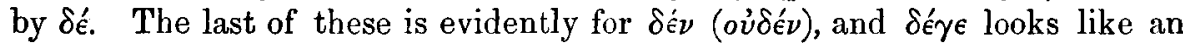
extension of it-hardly, as Morosi thinks, by the classical $\gamma \in$ é being affixed, for the day of particles with an independent meaning had passed away long before this word was created. Mava' is $\nu a i^{\prime}$ with $\mu a$ ' prefixed; but this $\mu a$ is more likely to have been the Italian for 'but,' which is frequently used in M. G., than the ancient particle; for the usage compare Fr. 'mais oui.' The

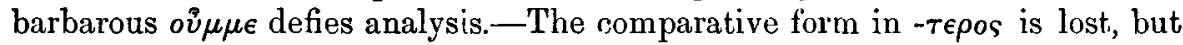
two comparatives, which are either lost or extremely rare in M. G., $\kappa a ́ \lambda \lambda \iota$, 'better;' and $\chi \epsilon \hat{\imath} \rho \circ$, 'worse,' are regularly in use here.-The aor. pass. is free from the accretion of $-\kappa a$, which is found in mediaeval and modern Greek, as

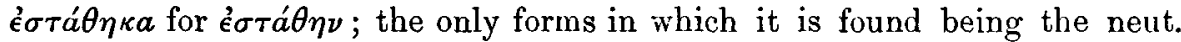

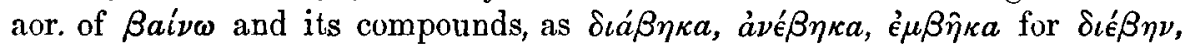

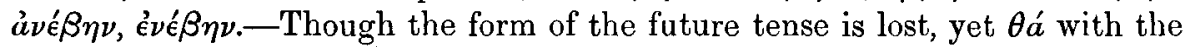
subjunctive, which has supplied its place in Greece, is wanting here; $\theta \dot{\theta} \lambda \omega \nu \boldsymbol{c}^{\prime}$ is used for 'I wish to,' and é $\chi \omega \nu$ ' for 'I have to,' 'I must,' but neither of them serves for the simple future. If $\theta a^{\prime}$ had been in use before these Greeks migrated to Italy, it would be strange if they had lost so serviceable a form; as it is, they can only express the future by the present combined

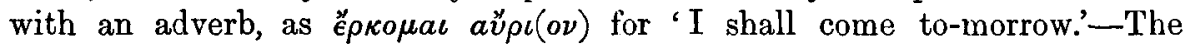
tendency to shift the accent of words on to the final syllable, the influence of which already shows itself in mediaeval Greek, and which appears almost like a trick in the modern language, is hardly found here (see above, p. 17).

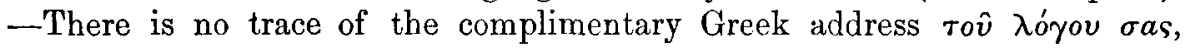
'your honour,' though this is found in embryo as early as the fourteenth

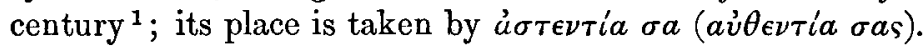

Again, the words of foreign importation-Slavonic, Albanian, Venetian, and Turkish-which have influenced so considerably the Modern Greek vocabulary, are here almost entirely wanting. The influence of the Slavonic languages, indeed, on Modern Greek, as Miklosich has shown in his valuable paper, Die slavischen elcmente im Neugriechischen, has not been extensive; but of the words which he there mentions as having this origin, only one, $\hat{\rho} o \hat{v} \chi a$, 'clothes,' seems to have found its way into Italy, and this may have been adopted into Greek at a comparatively early date. Albanian seems to be unrepresented, and the Venetian dialect of Italian almost entirely so, though in Greece from the fourteenth century onward, owing to the extensive dominion of the Republic in the East, it furnished many expressions which afterwards became naturalised. The question of Turkish words is a more difficult one, because it depends in part on the amount of confidence that is to be placed in a book published by Morelli at Naples in 1847, entitled Cenni storici intorno alle colonie greco-calabre. This work, which I have not seen, but which in the judgment of Morosi and Pellegrini is full of errors, contains in one part a list of words in use at Bova, among which are several of Turkish origin. For the existence of these Morelli seems to be the sole 
authority, and when I enquired about some of them on the spot I found them to be unknown; indeed, Morosi is led to suspect that they must have been obtained from some Calabrian Greek who had been in Greece. The name Tovpкo, it is true, occurs in the songs, but this proves nothing with regard to this point, since it is used generally in the sense of a 'corsair.' To ali this we may add what has already been remarked, that the regular ballad metre of the Greeks, and the familiar subjects of their songs, are wanting in Italy; and, moreover, that the popular mythology, with the well-known figures of Charon, the Nereids, \&c., ${ }^{1}$ which is everywhere else the inheritance of this people, is unknown here. This is the more striking, because the Greeks of Cargese in Corsica, who migrated from the Morea two centuries ago, and have ever since been cut off from communication with their countrymen, still retain the ballads which they brought with them, and speak a language but little different from that which is in use in southern Greece.

The proofs which have thus been accumulated to shew that the Greek which is spoken in Italy is mediaeval, and not simply modern, in its leading features are corroborated by a comparison of the dialects of the Terra d'Otranto and of Bova with one another. My readers cannot fail to have been struck with the correspondence between these where they mutually differ from ordinary Romaic, in respect of their preservation of classical words, as $\kappa \lambda a ́ \omega$, $\dot{\rho} \iota \gamma \hat{\omega}$; their use of words otherwise unknown, as $\tau \dot{i} \sigma \pi o, \kappa a \nu o \nu \hat{\omega}$; and their peculiarities of form and accent and meaning. From these we naturally conclude that the two were derived from a common original dialect, which was in use in Italy at one time as an independent language, distinct from that which was spoken in Greece. On the other hand, the differences between the two dialects are sufficiently strongly marked to prove that the period when they were one is of considerable antiquity. Thus, to take a few instances out of many, the consonants $\kappa, \gamma, \tau, \delta, \beta, \nu$, which as a rule are lost between vowels in Otr., are usually kept in Bov.; $\delta$ is pronounced in Otr. as Eng. $d$, in Bov. as Eng. soft th; $\theta$ never retains its aspirated sound in Otr., but almost always does so in Bov.; the combinations $\kappa \tau$ and $\chi \theta$, which in

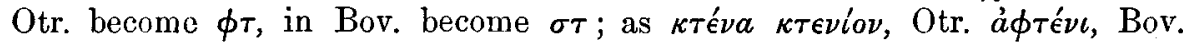

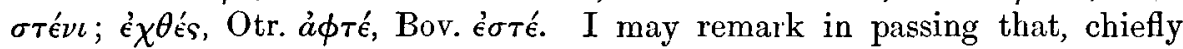
owing to the loss of internal consonants, the Otrantine dialect is much the more difficult of the two to understand. In that district I was informed that, when the inhabitants came in contact with a Greek from Greece-a thing which now and then happens, and is only natural owing to the proximity of the two countries, since on a clear day Corfu is in sight from that neighbourhood - they have great difficulty in comprehending his language; whereas my informant at Bova assured me that he had met such a Greek at Reggio, and that, when he spoke slowly, he could understand very fairly what he said.

Still, notwithstanding the evidences of antiquity which have been

1 On these, my Highlands of Turkey, vol. ii. pp. 304 foll., may be cousulted. 
mentioned, there are various features in these dialects which it is difficult to regard as otherwise than comparatively modern. The study of mediaeval Greek is hardly, perhaps, as yet sufficiently far advanced for us to be able to say with confidence at what period a particular word or form first appeared; but it is certainly striking that, whereas in the Italian Greek the words used for 'not' are corruptions of $\delta \delta^{\prime} \nu$, in the mediaeval chronicle of the Conquest of the Morea, which was written in the Peloponnese in the fourteenth century, this form does not occur, but only oúdé $\nu$ in the same sense. M. Psichari, however, in his lately published work, Essais de grammaire historiqu né-grecque, has furnished us with a test by which the periods of development of the modern Greek language may be approximately determined. By a careful examination of all the available compositions in popular mediaeval Greek he has shewn, that until the beginning of the fourteenth century the nom. plur. fem. of the article was $a i$ and the accus. $\tau a$ s, but that from that time onward oi $(\dot{\eta})$ began to take the place of the former, and tés (taís) of the latter, ${ }^{1}$ until in the course of the two following centuries they respectively drove out the earlier forms. Now we find that in Otr. the nom. plur. fem. is $a i$ and the accus. $\tau$ és, while in Bov. the nom. is oi and the accus. Tés. The conclusion to which this brings us is that, unless the correspondence in these changes in Greece and Itaiy is accidental-which it is difficult to supposethe Otrantine dialect must have been in some degree, that of Bova considerably, exposed to the influence of the language spoken in Greece subsequently to the thirteenth century.

Let us now enquire how far the results at which we have arrived by examining the language are borne out by the evidence of historical documents. With regard to the dying out of ancient Greek in the south of Italy, Strabo tells us that in his time the whole of that country, with the exception of the cities of Tarentum, Rhegium, and Naples, had been completely barbarised ( $\kappa \kappa \beta \epsilon \beta a \rho \beta a \rho \hat{\omega} \sigma \theta a \iota)$, i.e. that it had ceased to use the Greek tongue ${ }^{2}$; and from the absence of Greek inscriptions of the imperial period in that district-as far as the present state of our knowledge justifies us in speaking on the subject-we may conclude that that language became extinct there within the first, or at the utmost the second, century after Christ. From that period onward no considerable influx of Greeks into Italy took place until the outbreak of iconoclasm in the Eastern empire in the eighth century. At that time, owing to the persecutions to which the image-worshippers were exposed and their unwillingness to resign their cherished observances, large numbers of Byzantine Christians, especially of monks, left their homes, and settled in Apulia and Calabria; and the movement thus set on foot assumed so great proportions, that we are told that in the course of the eighth, ninth, and tenth centuries as many as two hundred Greek monasteries were erected in south Italy, and were subject to the

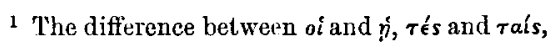
is one of orthography, for the pronunciation in each case is the same; there is no need here to discuss the question, which of the two is prefer- able, though it is important in determining the origin of these forms.

2 Strabo, vi. 1. \$2, p. 253. 
patriarch of Constantiuople.' But as the monks are gens in qua nomo nascitur, and with the final cessation of iconoclasm in the middle of the ninth century the primary cause of their emigration was removed, there must have existed on the spot a large number of their coreligionists to furnish inmates for those institutions. Such a Greek population was provided through the reestablishment of Byzantine influence in south Italy at that period by the emperor Basil the Macedonian, who organised his possessions there into a province called the Theme of Langobardia. After Basil's death, when the rich widow Danielis of Patrae (Patras), whose adopted son he was, left her immense possessions to his successor, Leo VI., that emperor enfranchised three thousand of her slaves, and established them in Apulia to cultivate the land as serfs. ${ }^{2}$ Subscquently to this the Greek e!ement must have greatly increased through the power exercised by the Byzantine officials, for we hear of as many as twenty important places, chiefly on the sea-coast, which were centres of their activity. ${ }^{3}$ After the final overthrow of the rule of the Eastern empire in these parts by the Normans in 1071, we have no definite evidence of any further reinforcement of these Greek colonies during the middle ages; though it is possible that in the time of the Comneni persons of this nationality may have been brought over to Italy by the Norman princes, first when Robert Guiscard and his son Bohemund invaded Greece, and afterwards when Roger II., after overrunning the country, carried off to Sicily the silk-workers of Thebes and Corinth. Nor can we overlook the close connexion which existed between the Kingdom of Naples and the Principality of the Morea in the latter part of the thirteenth and the beginning of the fourteenth century. ${ }^{*}$ Perhaps also at the time of the Ottoman conquest other Greeks may have fled hither for refuge, like those Albanians who crossed the Adriatic subsequently to the time of Scanderbeg, and whose settlements are still numerous in south Italy. But concerning the arrival of one additional colony at a later period we have certain information. Spon and Wheler mention that in 1673 , about the time of their visit to Greece, when the Turks were endeavouring to subjugate the Mainotes in the south of the Morea, more than two thousand persons of that race

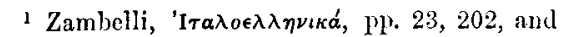
the authorities there given.

2 See Finlay, History of Greece, vol. ii. p. 255.

3 Zambelli, pp. 56, 57. In this connexion we may notice a remarkable group of words, which from haviug had a military application have come to be used of agriculture. In Otr. the term for 'tilling' the fields is $\pi \boldsymbol{\pi} \lambda \epsilon \mu \hat{\omega}$, and agricultural implements are called áppara, which is the regular word for 'arms' in mediaeval and modern Greek. Again, in Bov. the word for an agricultural labourer is $\pi \epsilon \zeta \delta$ 's 'a foot-soldier,' and that for 'a person' is $\theta \dot{\epsilon} \mu \alpha$, which also is said to have bcen previcusly used for ' $a$ cultivator of the soil.' The last word is used in Byzantine Greek first for ' a division of soldiers,' and then for the district in which they were stationed; whence it was technically used for the Themes of the Empire, and ultimately was equivalent to a geographical administrative division like the Theme of Langobardia just mentioned. It has been suggested by Morosi aud Pellegrini that the use of these expressions takes us back to the time of Byzantine military oecupation; and the hypothesis is a tempting one, for nothing corresponding to this change of meaning is found elsewhere among Greekspeaking peoples, so that it would seem to have been caused by cireumstances peculiar to the Italian colonies. When, however, it is applied to the words severally, it is difficult to see how it can be made to explain the change.

${ }^{4}$ See J. H. S. vol. ir. pp. 179-181. 
migrated to Apulia in order to preserve their independence, and had lands assigned to them there by the King of Spain. ${ }^{1}$ From Italian sources we learn that in 1674 a detachment of these, consisting of 175 inhabitants of Pressio in the Morea (i.e. probably Prastio, near Cardamyla), landed in the Terra d'Otranto, and were established at Mottola, a hill-town at the back of Taranto. When, however, an attempt was made to force them to adopt the Latin rite, they declined to submit, and betonk themselves to Tricarico, a p'ace further inland in the neighbourhood of Potenza. ${ }^{2}$ This took place about the same time that the Greek settlement was established in Corsica. We are further informed that in 1716 many families came from Greece to Lecce, and settled in that city and its neighbourhood. ${ }^{3}$

To turn now to the evidence furnished by Italy itself; we have ample proof from this source of an extensive Greek population existing in the country during the Middle Ages. In the Neapolitan archives there is a large collection of local Greek documents, ranging from A.D. 983 to 1304, and containing charters, agreements, forms of sale, \&c., the information contained in which has been sifted by Zambelli (Zampelios), and summarised in his

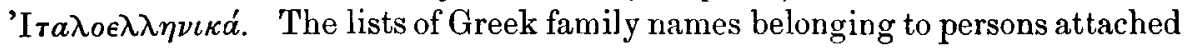
to farms and properties in various parts of the country, which occur in these, are very interesting, and the names correspond to a great extent to those which

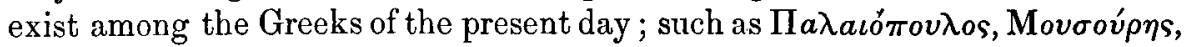

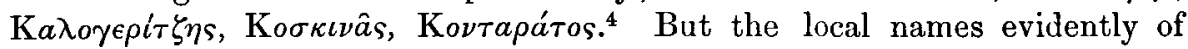
Greek origin which at the present day are widely spread over these provinces of Italy show that Greek was once used throughout a much more extensive area than any documents would seem to imply. Zambelli has collected more than fifty of these, which are found either there or in Sicily, and the following may

1 Spon, Voyage d'Italie \&c., Amst. 1679 vol. i. p. 122 ; Wheler, Journey into Greece, Lond. 1682 , p. 47. Among the Bova songs there is one that turns on the subject of 'the Greek girl' (i 'P Turkish lover, notwithstanding her mother's solicitations (Comparetti Nos. 36, 37 ; Pellegrini, No. 62). This poem differs completely in metre and mode of treatment from all the rest that are found in Italy, and corresponds to two on the same subject which are sung in Greece, Nos. 574 and 574a in Passow's Carmina popularia Graeciae recentioris ; there can be no doubt therefore that it has been imported from abroad. Morosi ('Bova,' p. 74), mentions a story which was current at Bova, to the effect that it had been introduced early in the present century by a native of that place who had lived abroad. If this was not the case, it is probable that it dates from the time of the migration of the Mainotes.

2 Rodotà, Dell' origine del rito greco, vol. iii. p. 96.

3 Aar, in Archivio storico italiano, 4th ser. vol. vi. ए. 316.
4 Zambelli, p. 168. It is also noticeable, as illustrating the numerous points of correspondence which exist between modern and early mediaeval Greek, how many words and peculiarities of form which are familiar at the present day are found in these early documents. Thus 'water' is $\nu \in \rho o ́ v$, the 'nose' $\mu \nu$ in, 'a dog' $\sigma \kappa u ́ \lambda \lambda o s$, 'oil ' $\lambda a ́ \delta$, 'a goat' $\gamma^{\prime} \delta a$, ' the summel',

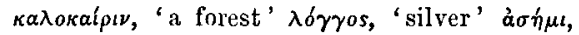

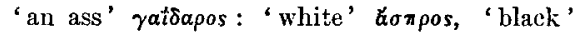

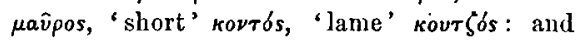
(to illustrate peculiarities of form) for àé $\rho \alpha$,

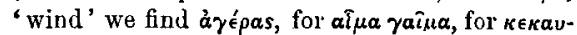

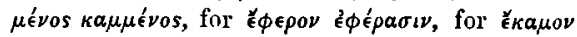
éќ́́ $\mu \alpha \sigma \iota$. (Zambelli, pp. 154, 171, 184, 185). It may be added, that in the Greek of the Bova district at the present day there are words in use which exist in Greek MSS. of Calabria earlier than Cent. xiii,, but do not belong to

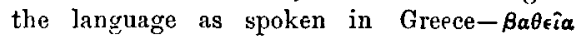

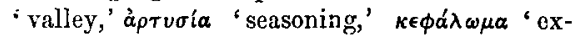

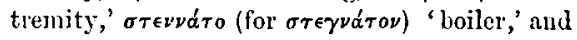
others. (Morosi, 'Borm,' p. 75.) 


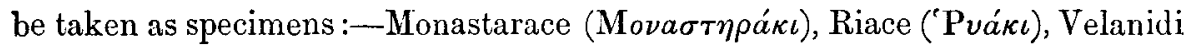

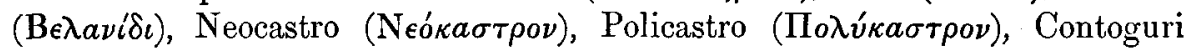

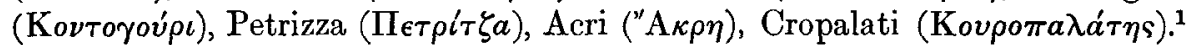
An additional and very curious form of evidence is supplied by the numerous mediaeval Greek words which are found embedded in the modern Apulian and Calabrian dialects of Italian. Thus the 'tortoise' is celona ( $\chi \in \lambda \omega ́ \nu \eta$ ), 'a frying-pan' tiane (

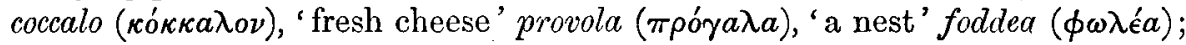
and there are many others. ${ }^{2}$

With regard to the two groups of Greek townships and villages which are the subject of this paper we have information of a fairly early date, and in both cases we discover that at one period they extended more widely than they do at the present day. In the case of the Terra d'Otranto the intimations occur at sufficiently frequent intervals to form a continuous chain of evidence from early in the middle ages to the present time. These have been collected with great care and learning by Sig. Aar in his articles entitled Gli studi storici in Terra d'Otranto in vols. vi. and ix. of ser. 4 of the Archivio storico italiano; ${ }^{3}$ and for the earlier period are derived from Greek manuscripts, like those already mentioned, in the Neapolitan and other archives, and from incidental notices in other documents. Thus a bull of Urban VI. in 1384 informs us that the town of Galatina, between Lecce and Gallipoli, had then a mixed population of Greek and Latin Christians, but that the services of the Church were conducted only in the Greek tongue. From this period onward the number of our authorities increases. Early in the fifteenth century Epifauio, abbot of Nardò, near Galatina, mentions many places inhabited by Greeks, whose number amounted to 12,330 souls. At the beginning of the following century Galateo, who was a native of these parts, in his book De situ Iapigiae makes mention of other towns where Greek was spoken; and this was confirmed during the sixteenth century by Alberti in his Descrittione di tutta l'Italia, by Porzio in his Relazione del regno di Napoli, and by Persio in his Discorso intorno alla conformitd della lingua italiana con le piu nobili antiche lingue. Further evidence on the same subject is furnished in the first half of the seventeenth century by Arcudi, priest of Soleto, who in a letter addressed to Pope Urban VIII. describes the Greek that was in use in that place; and in the early part of the eighteenth century by Ughelli in his Italia Sacra." Of the Greeks of Bova the first notice is found in a charter (without date) of Roger II., who died in 1154: in this, among the serfs presented by him to a monastery in Calabria, we find $\Gamma \rho \eta \gamma o$ o

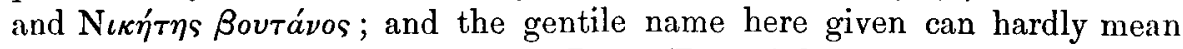
anything else than 'inhabitant of Bova (Bova), being in fact the name

\footnotetext{
1 Zambelli, pp. 54, 55 ; cp. Morosi, Stucli, 206.

2 Zambelli, p. 68 ; cp. Morosi, Studi, p. 206.

3 Proofs of the existence of a much more numerous Greek population are given in vol. vi. pp. 101, 102, and notes. For evidence on the
}

same subject derived from the continuance of the Greek rite in Italy the reader is referred to an article in the Antiquary for 1888, pp. 195197.

4 See the authorities in Morosi, Studd, 1$\}$. 181, 207, and Pellegrini, pp. ix -xi. 


\section{THE GREEK-SPEAKING POPULATION OF SUUTHFIN I'TALY.}

applied to the people of that place at the present day.l At a later period they are explicitly mentioned by Barrio in his De anliquitate et situ Calabriae (Rom. 1571). After mentioning various other places in that province where Greek was spoken, that writer names 'Bova civitas, sedes episcoplalis in montis cacumine sita,' and then adds-'A Leucopetra villa hucusque incolae in familiari sermone Latina (i.e. Italian) et Graeca lingua utuntur, sacra vero Graeca lingua, Graecoque ritu faciunt.' 2

The conclusion, then, to which we are led with regard to the origin of the Greek-speaking population of South Italy is, that they are descendants of the Byzantine Greeks who migrated thither not later than the eleventh century, and that the groundwork of their language is to be found in the Greek that was spoken in Greece at that time. But, notwithstanding that we have no definite evidence of any other immigrants having come over from the mother-country between that date and the seventeenth century, yet so great difficulty is involved in supposing that all the forms and expressions which these dialects possess in common with Modern Greek existed so early, that we are almost forced to the conclusion that the original colonies must at some time have been reinforced in this manner. We have seen that it is a doubtful question whether any Turkish words are to be found in the Italian Greek at the present day. If this should prove to be the case, their introluction may with some confidence be referred to the migration from Greece which took place in 1673 ; and other peculiarities in the language, which can be proved to bear a comparatively modern stamp, may not unreasonably be attributed to that period.

H. F. Tozer.

1 Morosi, 'Bora,' p. 76.

2 Barrius, p. 228, quoted by Pott in Philo?ognes, vol. xi. p. 247. 